Review

\title{
Sialosignaling: Sialyltransferases as engines of self-fueling loops in cancer progression
}

\author{
Fabio Dall'Olio a, ${ }^{\mathrm{a}}$, Nadia Malagolini $^{\mathrm{a}}$, Marco Trinchera ${ }^{\mathrm{b}}$, Mariella Chiricolo ${ }^{\mathrm{a}}$ \\ a Department of Experimental, Diagnostic and Specialty Medicine (DIMES), University of Bologna, Bologna, Italy \\ b Department of Medicine Clinical and Experimental (DMCS), University of Insubria Medical School, Varese, Italy
}

\section{A R T I C L E I N F O}

\section{Article history:}

Received 4 April 2014

Received in revised form 13 May 2014

Accepted 10 June 2014

Available online 17 June 2014

\section{Keywords:}

Glycosylation

Sialylation

Gangliosides

Neural cell adhesion molecule

Integrins

Chemoresistance

\begin{abstract}
A B S T R A C T
Background: Glycosylation is increasingly recognized as one of the most relevant postranslational modifications. Sialic acids are negatively charged sugars which frequently terminate the carbohydrate chains of glycoproteins and glycolipids. The addition of sialic acids is mediated by sialyltransferases, a family of glycosyltransferases with a crucial role in cancer progression.

Scope of the review: To describe the phenotypic and clinical implications of altered expression of sialyltransferases and of their cognate sialylated structures in cancer. To propose a unifying model of the role of sialyltransferases and sialylated structures on cancer progression.

Major conclusions: We first discuss the biosynthesis and the role played by the major cancer-associated sialylated structures, including Thomsen-Friedenreich-associated antigens, sialyl Lewis antigens, $\alpha 2,6$-sialylated lactosamine, polysialic acid and gangliosides. Then, we show that altered sialyltransferase expression in cancer, consequence of genetic and epigenetic alterations, generates a flow of information toward the membrane through the biosynthesis of aberrantly sialylated molecules (inside-out signaling). In turn, the presence of aberrantly sialylated structures on cell membrane receptors generates a flow of information toward the nucleus, which can exacerbate the neoplastic phenotype (outside-in signaling). We provide examples of self-fueling loops generated by these flows of information.

General significance: Sialyltransferases have a wide impact on the biology of cancer and can be the target of innovative therapies. Our unified view provides a conceptual framework to understand the impact of altered glycosylation in cancer.
\end{abstract}

(C) 2014 Published by Elsevier B.V.
Abbreviations: ALL, acute lymphocytic leukemia; AML, acute myeloblastic leukemia; 5-AZA, 5'-azacytidine; BCG, Bacillus Calmette-Guerin; CIN, chromosome instability; DP, degree of polymerization; ECM, extracellular matrix; EGF, epidermal growth factor; EGFR, epidermal growth factor receptor; EMT, epithelial to mesenchymal transition; ER, estrogen receptors; ERE, estrogen responsive element; ERK, extracellular signalregulated kinase; FAK, focal adhesion kinase; Gal, Galactose; GalNAc, Nacetylgalactosamine; GlcNAc, N-acetylglucosamine; MAPK, mitogen-activated protein kinase; MSI, microsatellite instability; MSS, microsatellite stability; MUC1, mucin-1; N-CAM, neural cell adhesion molecule; PCR, polymerase chain reaction; PI3K, phosphatidylinositol-4,5-bisphosphate 3-kinase; PIP3, phosphatidylinositol $(3,4,5)$-triphosphate; PSA, polysialic acid; PST, polysialyltransferase ST8SIA4; Sia, sialic acid; sT, sialyl-T; sTn, sialyl-Tn; Sia6LacNAc, $\alpha 2,6$-sialylated lactosamine; SNA, Sambucus nigra agglutinin; STX, polysialyltransferase ST8SIA2; TF, ThomsenFriedenreich; sLe $^{\mathrm{a}}$, sialyl-Lewis ${ }^{\mathrm{a}}$; sLe $^{\mathrm{x}}$, sialyl-Lewis ${ }^{\mathrm{x}}$; TGF- $\beta$, transforming growth factor- $\beta$; TNF- $\alpha$, tumor necrosis factor- $\alpha$; VEGF, vascular endothelial growth factor; VEGFR, vascular endothelial growth factor receptor

* Corresponding author at: Department of Experimental, Diagnostic and Specialty Medicine (DIMES), General Pathology Building, Via S. Giacomo 14, 40126, University of Bologna, Bologna, Italy. Tel.: + 39051 2094704; fax: 390512094746

E-mail address: fabio.dallolio@unibo.it (F. Dall'Olio).

\section{Introduction}

The sugar portions of glycoproteins and glycolipids are often terminated by sialic acids ( $\mathrm{Sia}$ ): sugars which, owing to their negative electric charge, are crucial in regulating molecular and cellular interactions [1-3]. Sialic acids can be linked to subterminal sugars through an $\alpha 2$ 6-bond to $\mathrm{N}$-acetylgalactosamine (GalNAc) or N-acetylglucosamine (GlcNAc); an $\alpha 2,3$ or $\alpha 2,6$ bond to galactose (Gal) or through a $\alpha 2-8$ bond to another sialic acid, forming polysialic acids. Sialyltransferases are a class of glycosyltransferases which catalyze the transfer of sialic acid from a common donor substrate (CMP-sialic acid) to a carbohydrate chain. Sialyltransferases show a certain degree of redundancy, in that the same glycosidic linkage can often be elaborated by different gene products [4] and are crucially involved in cancer progression [5, 6]. In this review we have summarized the studies showing the intimate relationship between sialyltransferases and their products with the mechanisms of cell transformation and cancer progression. In particular, we provide examples of how the signaling generated by sialylated molecules at the cell membrane can activate self-amplification loops fueling cancer growth. 


\section{Overall effect of sialylation in cancer}

Early studies indicated that the level of sialyltransferase activity is often increased in plasma of cancer patients [7-10] and that the extent of sialylation of cancer cells is associated with their invasive properties [9,11-18]. Former functional studies on the overall effect of sialic acids in cancer biology, using sialidases or sialyltransferase inhibitors sometimes provided contradictory results [19]. For example, the effect of sialidase treatment on collagen IV adhesion was the opposite in murine and human cancer cells [13,14], while sialic acid depletion by the sialyltransferase inhibitor KI-8110 reduced metastasis formation [20] without affecting cell adhesion to extracellular matrix glycoproteins but rather decreasing platelet aggregation [16]. According to other studies, the inhibition of sialic acid incorporation by different compounds impaired adhesion, migration, in vivo tumor growth and metastasis formation [21-25].

\section{Sialylated structures involved in cancer progression}

In this section we describe the structure and biosynthesis of specific sialylated structures and discuss their contribution to cancer biology and progression.

\subsection{Thomsen-Friedenreich (TF)-related antigens}

Antigens T, Tn and their sialylated variants sialyl-T (sT) and sialyl-Tn (sTn) are small cancer-associated O-linked structures, often referred to as Thomsen-Friedenreich (TF)-related antigens [26], whose structure and biosynthesis are depicted in Fig. 1.

In breast cancer, mucin glycosylation undergoes a characteristic switch from the expression of core 2 structures to the accumulation of $\mathrm{T}$ [27] and sTn structures [28,29]. This change is accompanied by a concomitant and apparently paradoxical up-regulation of sialyltransferase ST3GAL1 [30], which converts T in sialyl-T (sT) antigen [31], inhibiting the synthesis of core-2 based structures [32]. ST3GAL1 overexpression in breast cancer is associated with conditions characterizing tumor growth, such as the presence of the inflammatory enzyme cicloxygenase-2 (COX-2) and of its product prostaglandin E2 (PGE2) [33] and hypoxia [34]. On the other hand, the expression of the cell membrane mucin 1 (MUC1), which is frequently altered in cancer [35], down-regulates ST3GAL1 expression in mouse mammary carcinoma cells [36]. Constitutive ST3GAL1 expression by murine mammary epithelium contributes to breast cancer progression. In fact, in PyMT mice, which spontaneously develop breast cancer, the concomitant over-expression of ST3GAL1 in mammary glands results in the development of mammary tumors with shorter latency, although no accumulation of sT antigen was observed [37]. Altogether, these data suggest that the biological effect of ST3GAL1 on cancer progression might not be dependent on the synthesis of its cognate carbohydrate antigen, but rather on its proposed tumor promoter activity [37]. A paradoxical over-expression of both $\mathrm{T}$ antigen [38] and sialyltransferases ST3GAL1 and ST3GAL2 [39] has also been reported in colon cancer, with the former associated with lymph node metastasis [39]. In bladder cancer tissues ST3GAL1 mRNA was also elevated, particularly in patients with tendency to recurrence [40].

sTn, a pan-carcinoma antigen expressed by many malignancies [41-45], is usually associated with a worse prognosis [46]. The biosynthesis of sTn largely depends on sialyltransferase ST6GALNAC1, while the contribution of ST6GALNAC2 appears to be negligible $[47,48]$, being more specific for s6T biosynthesis. However, the reduced Oacetylation of sialic acid [49] and the down-regulation of the competing core 1 galactosyltransferase [50,51] also contribute to increased sTn expression in cancer [52]. In bladder cancer, sTn is expressed by $75 \%$ of high-grade tumors and correlates with ST6GALNAC1 expression [45]. Moreover, the expression of this carbohydrate antigen, associated with s6T, is a marker of disease-free survival and predicts response to immunotherapy with bacillus Calmette-Guerin (BCG) [45]. In different cancer cell lines, the phenotypic effects of sTn over-expression obtained by forcing ST6GALNAC1 expression, are multiple and only partially overlapping. These include: morphological changes and reduced ability to migrate on extracellular matrix (ECM) components [53], reduced cell adhesion and increased cell migration [54-56], increased metastatic ability [57], decreased intercellular aggregation and increased ECM adhesion, migration and invasion [58], increased cell motility and invasion

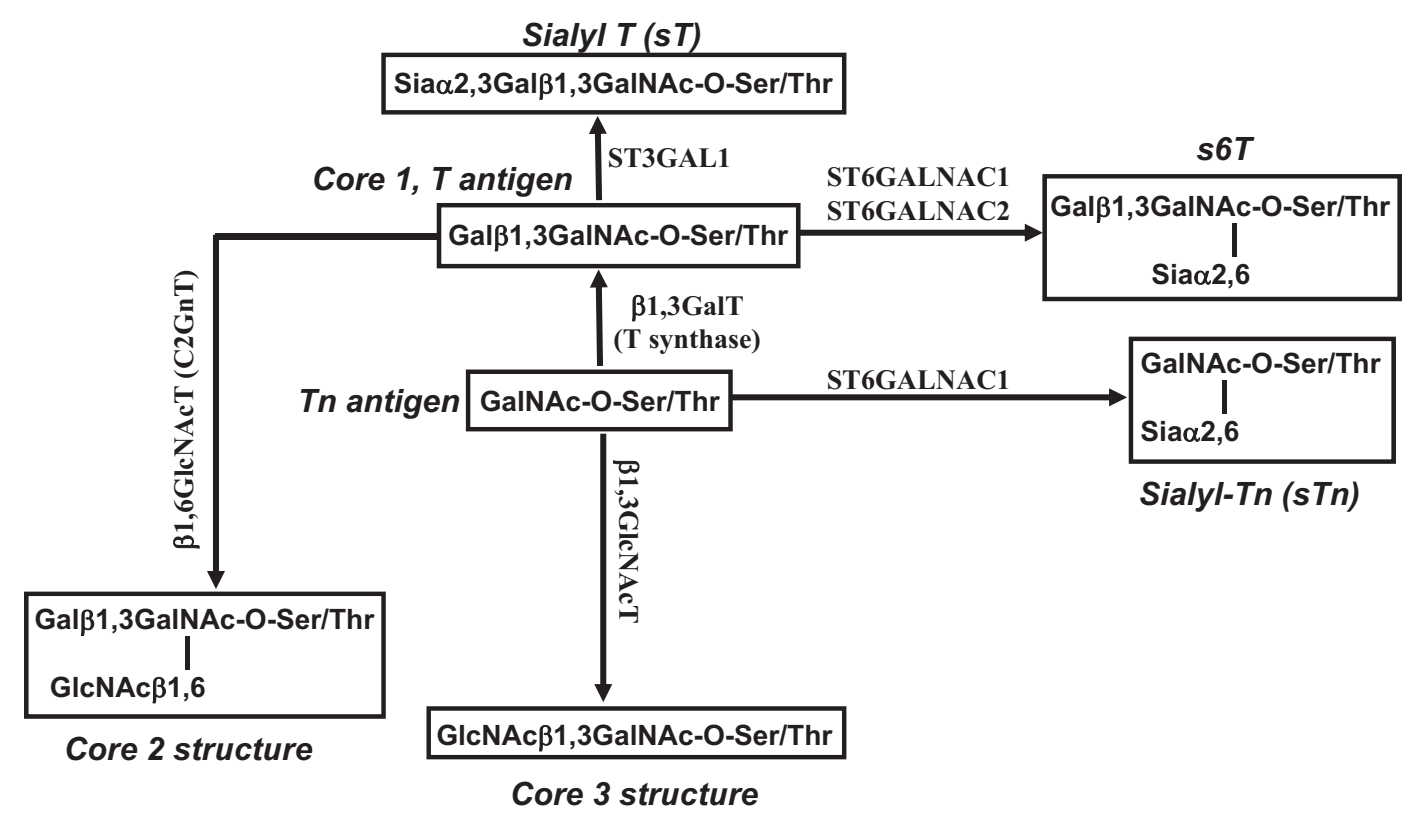

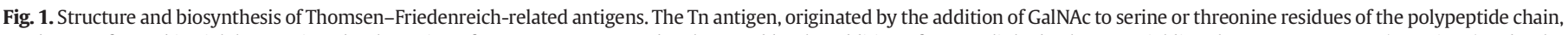

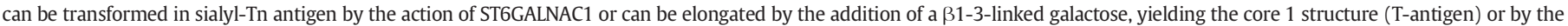

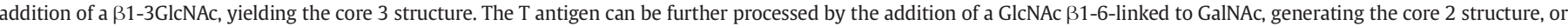

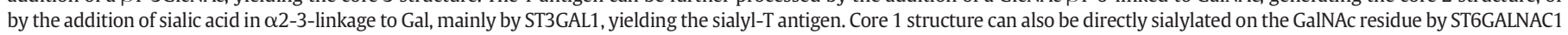
or ST6GALNAC2, yielding s6T antigen. 
[44]. A possible mechanism through which sTn could enhance tumor growth in vivo involves the interaction with Siglec 15, a member of the Siglec family of sialic acid binding lectins [59], expressed by macrophages. sTn binding by the tumor-associated macrophages, which usually display an immunosuppressive M2 phenotype, triggers TGF- $\beta$ release, establishing a microenvironment favoring cancer growth [60]. The ability of sTn-expressing cells to induce a tolerogenic phenotype of innate immune cells has recently been observed in a different model system [61].

Expression of ST6GALNAC2 displays opposite effects in colon and breast cancer. In colon cancer it is associated with lymph-node metastasis and poor survival [39], while in breast cancer it suppresses brain metastases [62]. The latter effect is due to the replacement of the $\mathrm{T}$ antigen with s6T with the consequent block of the binding of galectin-3 to membrane glycoconjugates, a key step in brain metastasis formation [62].

\subsection{Sialyl Lewis antigens}

Sialyl Lewis ${ }^{\mathrm{a}}\left(\mathrm{sLe}^{\mathrm{a}}\right)$ and sialyl Lewis ${ }^{\mathrm{x}}\left(\mathrm{sLe}^{\mathrm{x}}\right)$ are type 1 or type 2 fucosylated antigens terminated by $\alpha 2,3$-linked sialic acid [63], whose structure and biosynthesis are depicted in Fig. 2 . Their relevance in cancer mainly originates from their binding to E- and P-selectins expressed on activated endothelial cells [64]. The ectopic expression of sLe antigens by cancer cells allows the adhesion to endothelial cells, promoting metastasis [65], tumor growth and angiogenesis [66]. Experimental

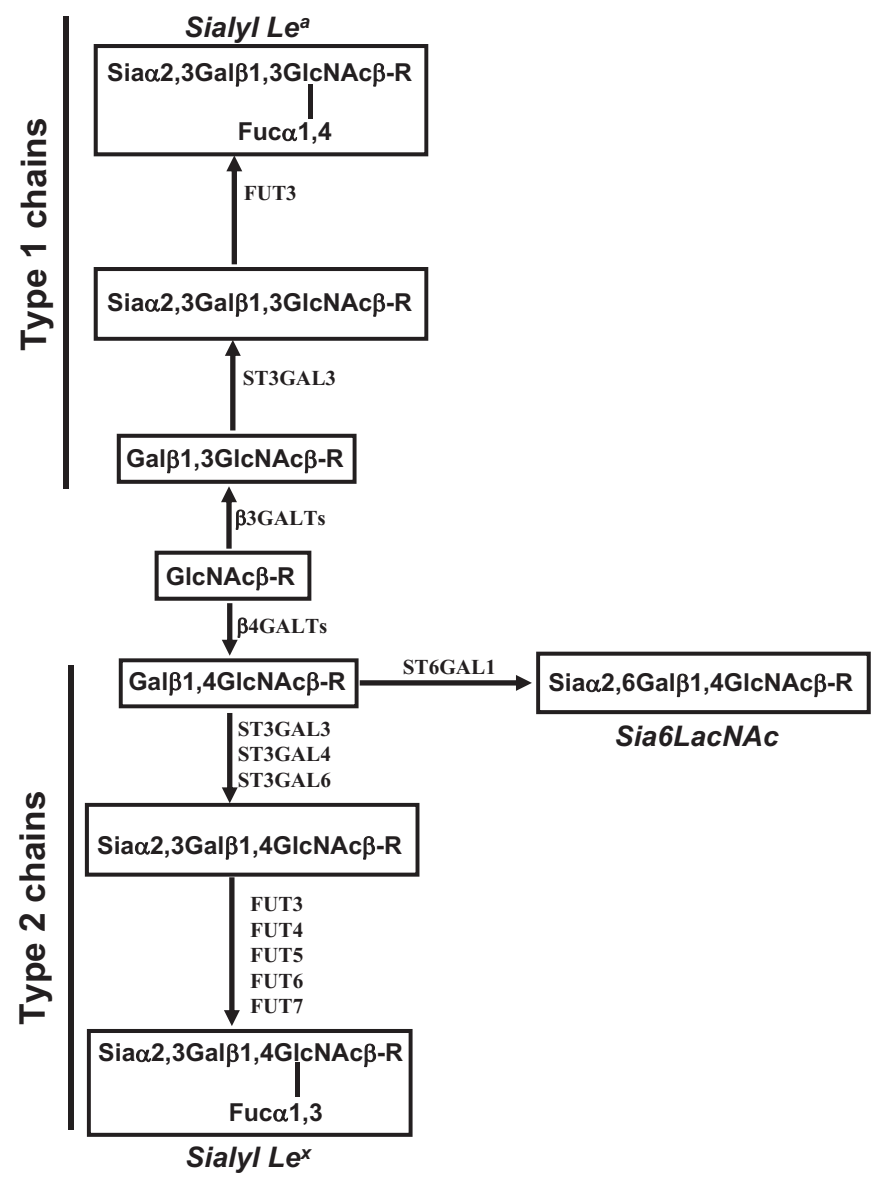

Fig. 2. Structure and biosynthesis of sialy Lewis antigens and Sia6LacNAc. Substitution of GlcNAc by a $\beta 1,3$-linked galactose leads to the basic unit of type 1 chain, while substitution with a $\beta 1,4$-linked galactose leads to lactosamine, the basic unit of type 2 chains. $\alpha 2,3-$ sialylation of type 1 or 2 chains by the indicated sialyltransferases forms the substrates for the successive addition of fucose, which is mediated by FUT3 in sLe ${ }^{\mathrm{a}}$ biosynthesis and by FUT3, $-4,-5,-6$, or -7 in sLe ${ }^{\mathrm{x}}$ biosynthesis. The $\alpha 2,6$-sialylation of type 2 chains by ST6GAL1 leads to the formation of Sia6LacNAc. manipulation of $\alpha 2,3$-sialyltransferases [67-72] and/or $\alpha 1,3 / 4$ fucosyltransferases [73-75] indicates that both enzymes classes can determine the level of sLe biosynthesis, even though this does not necessarily imply a regulatory role in vivo for those enzymes. Studies on mRNA expression of sialyltransferases in clinical specimens had reported partially conflicting conclusions [76-78]. The lack of a clear relationship between sialyl-/fucosyltransferase modulation and sLe expression in colon cancer [76] suggests that in this malignancy, the de novo expression of sLe antigens might be due to other mechanisms (reviewed in $[79,80]$ ). TNF- $\alpha$ stimulates the expression of selectin ligands through different mechanisms: in lung cells through stimulation of ST3GAL4 [72,81], in prostate cancer cells through up-regulation of ST3GAL3 and other glycosyltransferases [82]. Epithelial to mesenchymal transition (EMT), a crucial event in metastasis formation of epithelial tumors, induced by EGF or bFGF treatment of colon cancer cells, produced expression of sLe $^{\mathrm{x}} / \mathrm{sLe}^{\mathrm{a}}$ antigens [83] through the transcriptional activation of sialyltransferases ST3GAL1, -3- and -4 (and of FUT3), mediated by c-myc [83]. The transcription of ST3GAL6, also involved in sLe ${ }^{\mathrm{x}}$ biosynthesis, is increased by treatment with 5 -aza-2'-deoxycytidine, a drug which inhibits DNA methylation [84]. It is likely that the altered pattern of methylation of tumors influences the expression level of sialyltransferases involved in the biosynthesis of sialylated tumor antigens. In breast cancer, high ST3GAL3 mRNA expression, together with low ST6GAL1, are associated with worse prognosis $[85,86]$. Breast cancers are grouped according to the expression of the estrogen receptors (ER). The privileged expression of $\mathrm{sLe}^{\mathrm{x}}$ by ER-negative tumors is consistent with the over-expression of a group of glycosyltransferases, including ST3GAL6, FUT3, and FUT4 [87]. Although expression of sLe ${ }^{\mathrm{x}}$ is not directly associated with survival, patients displaying a double $\mathrm{sLe}^{\mathrm{x}} / \mathrm{ER}$ positive phenotype are at higher risk of metastasis to bone where E-selectin, the countereceptor of $\mathrm{sLe}^{\mathrm{x}}$, is constitutively expressed [87].

\subsection{Polysialic acid}

Long linear arrays of sialic acid residues joined through an $\alpha 2-8$ linkage which decorate the $\mathrm{N}$-linked chains of the neural cell adhesion molecule (N-CAM) [88] and of a few other glycoproteins are referred to as polysialic acid (PSA). The biological properties of PSA depend on the degree of polymerization (DP), which is high in embryonic and fetal brain but low in the adult [89]. High DP PSA exerts a strong inhibitory effect on intercellular adhesion [90,91], allowing the tissue plasticity which characterizes immature nervous system. PSA regulates both homophilic interactions between N-CAM molecules and heterophilic interactions between N-CAM and other cell adhesion molecules [92]. The biosynthesis of PSA is mediated by two sialyltransferases, ST8SIA2 (also known as STX) [93] and ST8SIA4 (also known as PST) [94], which display only partially overlapping properties in that only ST8SIA2 is dependent on development while ST8SIA4 synthesizes longer PSA chains [95].

High DP PSA is re-expressed in a variety of human cancers [96] mainly, but not exclusively, of neuroectodermal origin $[97,98]$ and is usually associated with malignancy. In a seminal study on neuroblastoma cells, the DP of PSA was found to be greater than 55 [99]. In vitro, the presence of PSA increased cell growth and migration [100,101], while in immunodeficient mice PSA expression facilitated the growth of glioma cells in the brain [102] and increased metastasis formation [103], although it reduced the subcutaneous growth of lung cancer cells in nude mice [104]. The increased cell motility associated with high DP PSA can be explained by at least two different mechanisms: through decreased E-cadherin-mediated intercellular aggregation [92] and by decreased number of cell-substratum focal adhesions [105]. The contribution of the two polysialyltransferases to PSA re-expression is tissue-dependent $[98,102,106]$. Bone marrow detection of ST8SIA2 mRNA in neuroblastoma patients predicts metastatic progression [107]. The therapeutic inhibition of PSA biosynthesis has been pursued 
with different approaches [108]. In colon cancer, polysialyltransferases are expressed without a concomitant expression of PSA [104], because of the lack of N-CAM. Even though PSA has been associated with malignancy, N-CAM expression is associated with reduced invasion [109, 110]. This could explain why the concomitant transfection of lung adenocarcinoma cells with both polysialyltransferases and N-CAM cDNAs reduced in vivo growth [104]. Consistently, although neuroblastoma patients with higher levels of polysialylated N-CAM presented more often metastasis at diagnosis, those without polysialylated N-CAM had a poor five year survival [111].

\subsection{Sia6LacNAc}

The transfer of $\alpha 2,6$-linked sialic acid to lactosaminic chains (Fig. 2), mediated by $\beta$-galactoside $\alpha 2,6$-sialyltransferase (ST6GAL1) generates $\alpha 2,6$-sialylated lactosamine (Sia6LacNAc). Lectins from Sambucus nigra (SNA), Trichosanthes japonica [112] or Polysporus squamosus [113] have been widely used to detect Sia6LacNAc in normal and cancer tissues. The fucosylated variant of Sia6LacNAc recognized by antibody ST2H [114] and the CDw75 antigen [115] are also the product of ST6GAL1. Although widely expressed by normal tissues ST6GAL1 is a cancer-associated glycosyltransferase. After the first description of ST6GAL1 elevation in colon cancer tissues [116], successively confirmed by several groups [117-119], the enzyme and/or its product was found to be increased in a variety of malignancies (reviewed in $[5,120]$ ), as reported in Table 1. In colon cancer, increased SNA reactivity [121] and ST6GAL1 expression [122] have been reported to be predictive markers of poor prognosis. Colon cancers can be grouped according to two main transformation pathways. The majority display inactivation of the APC gene, mutation of K-ras and other changes. These cases usually show chromosomal instability (CIN) but microsatellite stability (MSS). The minority of the cases shows the inactivation of DNA repair genes, resulting in microsatellite instability (MSI), and a consequent inactivation of crucial tumor suppressor genes. The increased SNA reactivity of colon cancer cases is mainly associated with the MSS phenotype [123], probably because of the known dependence of ST6GAL1 on Ras activation (see Section 5.1), a key event in MSS progression.

While in rodent hepatoma ST6GAL1 was elevated [124,125], among liver cancer patients only a small group displayed increased ST6GAL1 expression [126,127], while the few patients with decreased expression [126] showed poor differentiation and prognosis [128]. Also in breast cancer, increased ST6GAL1 expression was displayed only by a group of patients, mainly of grade III [85].

An association between $\alpha 2,6$-sialylation and invasive growth was suggested by early studies [129-131]. However, to study the functional implications of the overexpression of ST6GAL1 and/or its cognate Sia6LacNAc structures, we [132] and successively others [133-135] obtained stable ST6GAL1 transfectants in different cell lines. These models showed increased $\alpha 2,6$-sialylation of $\beta 1$-integrins and increased binding to extracellular substrates in epithelial cancers [133,134,136-138]. The $\alpha 2,6$-sialylation of $\beta 1$-integrins modulates intracellular signaling (as described in Section 5.2) and is involved in a self-fueling loop (as described in Section 5.3). In addition, $\alpha 2,6$-sialylation of $\beta 1$-integrins can reduce the binding of galectin-3 [139] a lectin which, in some

Table 1

Human cancers displaying elevated ST6GAL1 and/or Sia6LacNAc.

\begin{tabular}{|c|c|c|c|c|c|}
\hline Tissue of origin & Enzyme protein & mRNA & Sia6LacNAc & References & Remarks \\
\hline \multirow[t]{15}{*}{ Colon } & Activity $^{\mathrm{a}}$ & - & - & [116] & \\
\hline & - & - & SNA & {$[236,237]$} & Low reactivity in adenomas \\
\hline & Activity & - & - & [118] & Increased in metastasis \\
\hline & Activity & - & SNA & [238] & \\
\hline & - & PCR & - & [77] & Detected in metastasis \\
\hline & Mab $^{\mathrm{b}}$ & - & - & [119] & \\
\hline & Mab & - & - & [122] & Worse prognosis \\
\hline & - & - & SNA & [121] & Worse prognosis \\
\hline & - & - & T. japonica & [112] & Only differentiated carcinomas \\
\hline & Activity & PCR & SNA & [239] & \\
\hline & - & PCR & - & [76] & \\
\hline & Activity & - & Anti CDw75 & [117] & \\
\hline & - & - & SNA & [123] & Reactivity mainly in MSS cases \\
\hline & - & - & SNA & [240] & Increased reactivity of some plasma proteins \\
\hline & Activity & - & - & [241] & \\
\hline \multirow[t]{3}{*}{ Stomach } & - & PCR & - & [242] & \\
\hline & Activity & PCR & - & [243] & Associated with local recurrence \\
\hline & - & - & Anti CDw75 & [244] & Worse prognosis \\
\hline $\mathrm{AML}^{\mathrm{C}}$ & Activity & - & - & [245] & Increased in blasts \\
\hline $\mathrm{ALL}^{\mathrm{d}}$ & - & PCR & $\mathrm{CD} 22^{\mathrm{e}}$ & [170] & Increased mRNA and Sia6LacNAc structures \\
\hline Choriocarcinoma & Activity & PCR & - & {$[246]$} & \\
\hline \multirow[t]{2}{*}{ Cervix } & - & PCR & - & [247-249] & \\
\hline & - & PCR & - & [250] & \\
\hline Ovary & - & PCR & - & [251] & \\
\hline Brain & Polyclonal Ab & Northern & SNA & [252] & Increased only in non-neuroectodermal tumors \\
\hline \multirow[t]{5}{*}{ Liver } & Mab & - & $\mathrm{CD} 22$ & [127] & \\
\hline & Activity & PCR, i.s. hyb ${ }^{f}$ & SNA & {$[126]$} & Increased in a minority of cases \\
\hline & - & PCR & Anti CDw75, & & Sia6LacNAc gangliosides slightly increased \\
\hline & - & - & Viscumin & [253] & ST6GAL1 mRNA unchanged \\
\hline & Activity & - & - & {$[128]$} & Decreased activity correlates with poor prognosis \\
\hline \multirow[t]{2}{*}{ Breast } & - & PCR & - & [85] & Associated with grade III \\
\hline & - & - & Anti CDw75 & [254] & \\
\hline \multirow[t]{2}{*}{ Mouth } & Activity & - & SNA & [255] & \\
\hline & Activity & - & SNA & [256] & Detected in serum \\
\hline Cutaneous cancers & Mab & - & - & [257] & Associated with invasion \\
\hline
\end{tabular}

a ST6GAL1 expression has been measured as enzyme activity.

b ST6GAL1 expression has been measured with a monoclonal antibody.

c AML: acute myeloblastic leukemia.

d ALL acute lymphocytic leukemia

e Sia6LacNAc has been detected using a soluble form of the Sia6LacNAc-specific siglec CD22.

f In situ hybridization. 
circumstances, can exert a pro-apoptotic effect [140], resulting in prevention of apoptotic death and increased malignancy. However, ST6GAL1 expression reduced the tumorigenic potential and the multilayer growth of the colon cancer cell line SW948 [137] and the invasive growth of glioma cells [135,141-143]. Mammary tumors developed by PyMT mice (Section 3.1) in a ST6GAL1-null background displayed increased differentiation but the same growth rate as those grown in the PyMT mice expressing ST6GAL1 [144], although ST6GAL1-negative tumors exhibited altered expression of genes associated with focal adhesion signaling and had decreased phosphorylation of focal adhesion kinase, a downstream target of $\beta 1$-integrins. The ST6GAL1 protein has been reported to be associated with the stem phenotype of both normal and cancer cells [145]. As detailed in Section 5.2, ST6GAL1-mediated sialylation prevents VEGF-independent angiogenesis [146,147]. Association of ST6GAL1 with radiation resistance and with drug resistance is discussed in Section 4. Altogether, these data indicate that the relationship between Sia6LacNAc and invasive growth is complex and probably strongly cell- and tissue-dependent.

\subsection{Gangliosides}

Gangliosides are sialic acid-containing glycosphingolipids, whose expression is often deranged in cancer. The two sialyltransferases which mainly control ganglioside biosynthesis are ST3GAL5 (GM3 synthase) which synthesizes GM3, precursor of all ganglio-series glycolipids, and ST8SIA1 (GD3 synthase) which synthesizes GD3, precursor of b-series gangliosides (Fig. 3). In general, it appears that malignancy is positively associated with the expression of GD3 [63,148,149] and negatively with that of GM3 [150-153]. A high level of GD3 characterizes melanoma, while neuroblastoma typically exhibit a high GD2/GD3 ratio, owing to high levels of B4GALNT1 (GD2 synthase) [154]. Neuroblastoma cells grown as nude mice xenografts express higher levels of ST8SIA1 and of b-series gangliosides [155], while knock-down of ST8SIA1 by antisense vector inhibited tumor growth and angiogenesis [156-158]. Enhanced malignancy in ST8SIA1-expressing cells can be due to interaction of GD3 or GD2 with integrins [159], growth factor receptors [160-162] and Src kinases [163] (Fig. 4) (discussed in detail in Section 5.2). A recent study [164] reports that ganglioside GD2 is a marker of breast cancer stem cells and that ST8SIA1 is a crucial regulator of GD2 expression. In this tumor, ST8SIA1 is regulated by NFkB and estradiol [165] (see Section 5.1). In considering the phenotypic effects of ST8SIA1 expression it should be considered that this enzyme also provides the basis for the biosynthesis of more complex gangliosides, such as GQ3 and GP3 [166]. A therapeutic approach of lung cancer based on ST8SIA1 suppression by RNA interference has been proposed [149].

The growth inhibitory effects of GM3 are supported by several observations. First, the growth-suppressing activity of GM3 is so strong that it can normalize the neoplastic phenotype induced by the expression of the viral oncogene v-Jun in fibroblasts [150] (Fig. 5); second, the expression of GM3 can induce cell death [167]; third, fibroblasts from ST3GAL5-KO mice, lacking a- and b-series gangliosides, show MAPK activation [168], indicating that the mere absence of GM3 even in the absence of GD3 is sufficient to activate the MAPK pathway. However, in oncogene-transformed cells a near complete ganglioside depletion results in a dramatic inhibition of in vivo growth in syngeneic animals [169]. Although ST3GAL5 and GM3 are usually associated with reduced malignancy, some observations suggest the opposite relationship [170-173]. The association between malignancy and ST8SIA1/ GD3 also presents some exceptions [174-176].

Sialyltransferases involved in the biosynthesis of more complex gangliosides are prominently involved in some cancers. ST6GALNAC5, which synthesizes GD1 $\alpha$ (Fig. 3), is a crucial mediator of breast cancer metastasis to the brain [177] because the ectopic expression by breast cancer cells of this enzyme, which is normally restricted to the brain, enhances their adhesion to brain endothelial cells and their passage through the blood-brain barrier. In other malignancies ST6GALNAC5 plays an opposite role. In fact, the CpG islands of its promoter are frequently hypermethylated in colon adenomas and carcinomas [178] while its over-expression in glioma cells lead to reduced malignancy [179]. The expression of ST6GALNAC6, another sialyltransferase involved in the biosynthesis of higher disialogangliosides, also shows down-regulation in cancer [180].

\section{Sialyltransferases in resistance to chemotherapy and radiotherapy}

Resistance to radio- and chemotherapy which are, beside surgery, the most widely used cancer therapies is a major reason of cancer death. A role of sialyltransferases in causing resistance to these treatments is

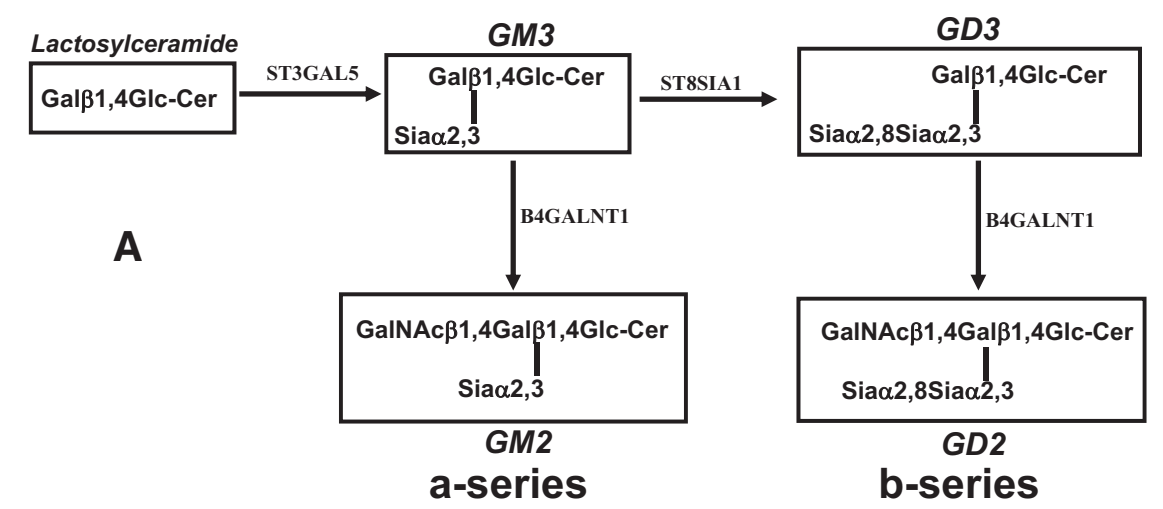

B
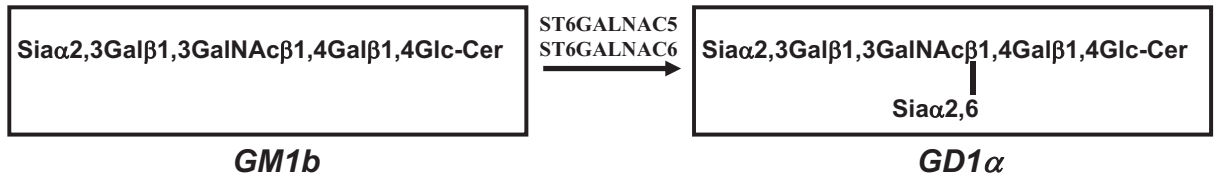

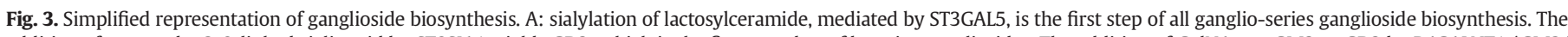

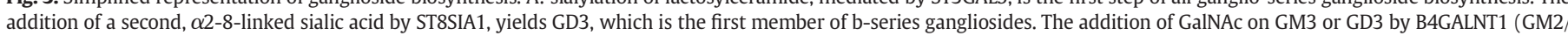
GD2 synthase) yields GM2 and GD2, respectively. B: biosynthesis of the brain metastasis-associated ganglioside GD1 $\alpha$ by ST6GALNAC5/ST6GALNAC6. 


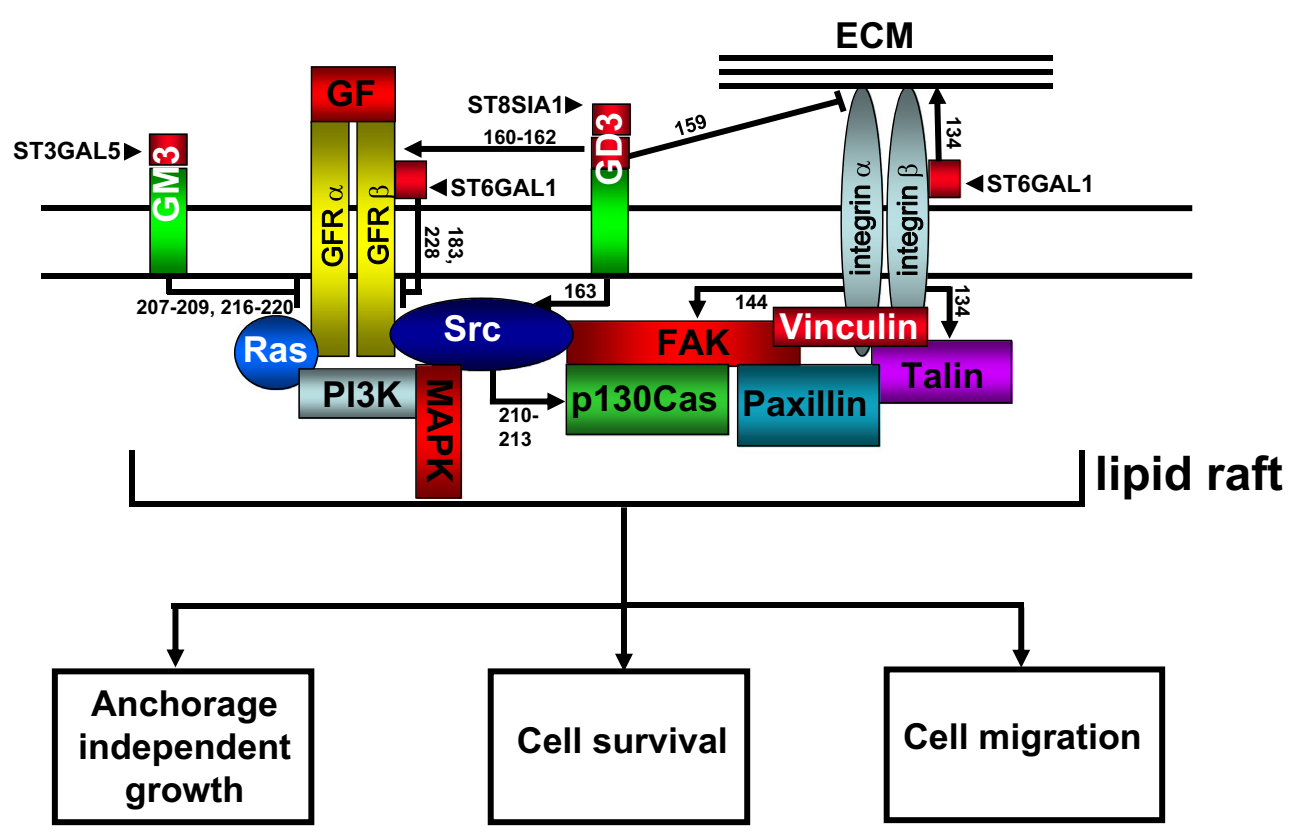

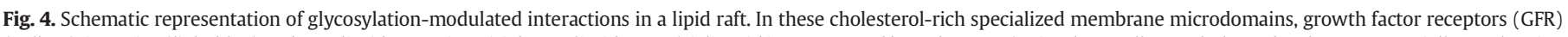

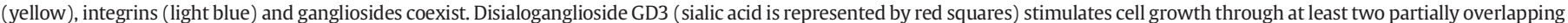

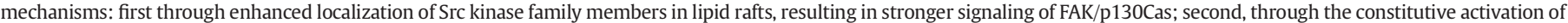

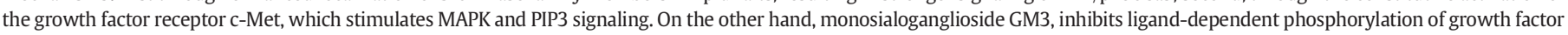

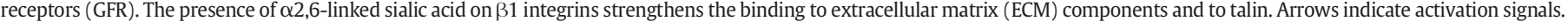
Arrowheads indicate the addition of sialic acid residues by specific sialyltransferases. Numbers close to arrows refer to some pertinent citations.

supported by several observations. ST6GAL1 expression confers drug resistance to ovarian cancer cells [181] and leukemia cells [182], while in a colon cancer cell line it reduces sensitivity to the EGFR kinase-specific inhibitor gefitinib [183]. On the other hand, human T cell lymphoblastic leukemia cells resistant to the drug desoxyepothilone B displayed reduced expression of ST6GAL1 [184]. Sialyltransferase ST8SIA4 is one of the glycosyltransferases over-expressed in a drug-resistant variant of the erythroleukemia cell line K562 [185] and in multidrug resistant variants of acute myeloid leukemia cells [182]. These changes affect expression of P-glycoprotein and of multidrug resistance-related protein 1 through modulation of PI3K/Akt signaling. Interestingly, Akt activation appears to be at the basis of ST6GAL1 and ST8SIA2 induced chemoresistance in hepatocarcinoma cell lines [186].

ST6GAL1 is also crucially involved in radiation resistance. In fact, exposure to ionizing radiations resulted in increased expression of ST6GAL1 in animal tissues and cultured cell lines $[187,188]$, while forced expression of ST6GAL1 cDNA in colon cancer cell lines induced radiation resistance [188]. The increased signaling through $\alpha 2,6$-sialylated $\beta 1$ integrins results in activation of paxillin and Akt signaling [189,190], promoting cell survival [191].

\section{Cancer associated glycans and signaling pathways}

Neoplastic transformation is usually due to altered regulation of genes regulating cell growth (oncogenes and tumor-suppressor genes). The carbohydrate structures described above are aberrantly expressed in cancer mainly because genetic and epigenetic changes alter oncogene/tumor suppressor gene regulation which, in turn, perturbs glycosyltransferase expression. Through the synthesis of cancer-associated carbohydrate structures, this generates a flow of information from the nucleus to the cell surface (inside-out signaling). On the other hand, membrane molecules decorated by cancerassociated glycans convey aberrant signaling pathways targeting gene expression, generating an information flow from the cell membrane to the nucleus (outside-in signaling). In some cases, these bi-directional information flows form self-fueling loops, as shown in Fig. 5.

5.1. Inside-out signaling: genetic and epigenetic changes leading to sialyltransferase modulation

ST6GAL1 provides a very good example of a glycosyltransferase which is directly controlled by an oncogene. The positive effect of Ras signaling on ST6GAL1 expression has been known since the '90s [192-194]. More recently, it has been shown that both oncogenic Nras and H-ras stimulate ST6GAL1 transcription through RalGEF signaling [195] and that in a colonocyte cell line Ras drives the $\alpha 2,6$-sialylation of $\beta 1$-integrins through ST6GAL1 over-expression [136]. Consistently, ST6GAL1 shows negative regulation by the tumor suppressor transcription factor RUNX3 [196]. On the other hand, it has been reported that ST6GAL1 expression is stimulated by caveolin-1 [197] a gene with a prevalent tumor suppressor activity.

Transfection of medulloblastoma cells with the muscle-specific transcription factor Pax3 induces polysialylation of N-CAM through increased expression of ST8SIA2 but not of ST8SIA4 [198].

Sialyltransferases display modulation by estrogens. Estradiol stimulates ST3GAL3 but inhibits ST6GAL1 in breast cancer cells [199]. The core promoter of ST8SIA1 contains two putative estrogen response elements (ERE) to which the transcription factor NFkB binds, stimulating transcription of ST8SIA1 [200]. However, in ER-positive breast cancer cells estradiol binding to ERE inhibits NFkB binding, resulting in down-regulation of ST8SIA1 transcription [165] and explaining the up-regulation of ST8SIA1 transcription in ER-negative breast cancers. Interestingly, in prostate carcinoma cells NFkB positively regulates the transcription of sialyltransferases ST3GAL1, -2 and -6 [201]. Sialyltransferases ST3GAL1, -3 and -4 are down-regulated by the metastasis-suppressor gene nm23-H1 [202] but are up-regulated by c-myc [83]. Although in porcine kidney cells, ST3GAL1 is transcriptionally regulated by TGF-B/SMAD3 signaling [203], in a human colon 


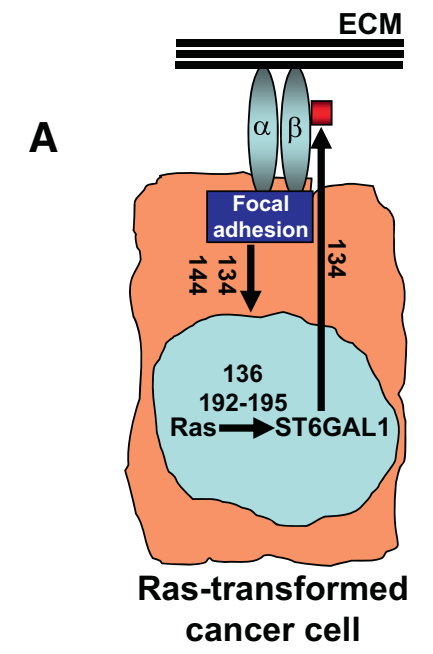

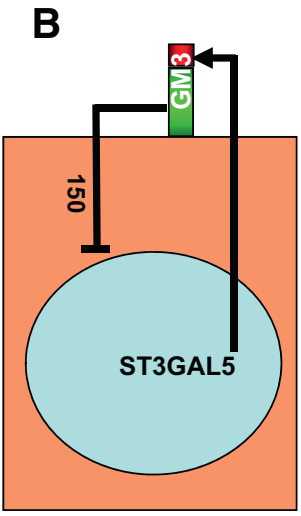

normal cell

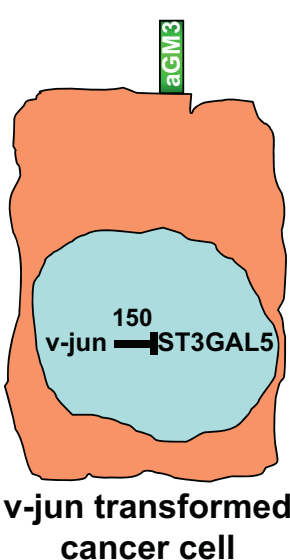

cancer cell

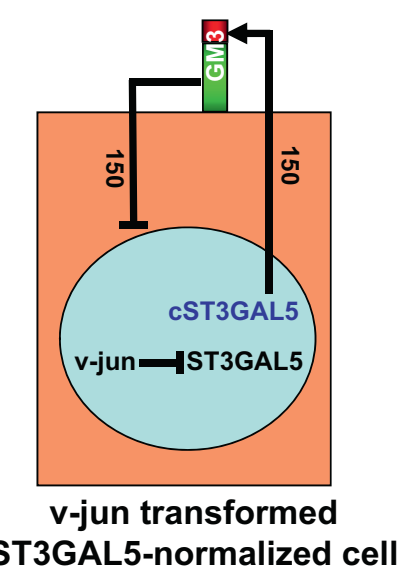

ST3GAL5-normalized cell

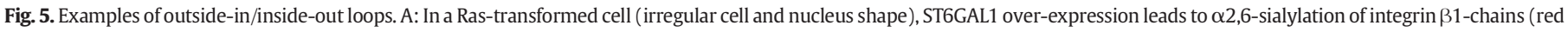

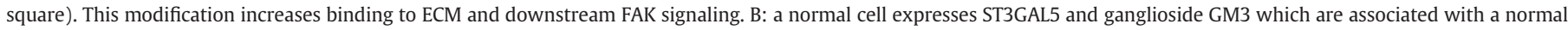

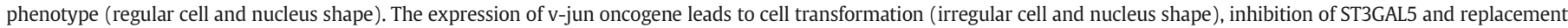

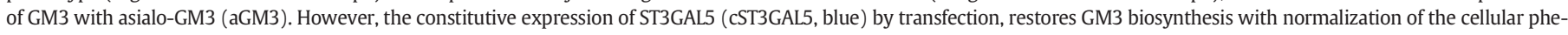
notype. Numbers close to arrows refer to pertinent citation.

cancer cell line TGF- $\beta$ receptor 2 signaling modulates sialylation without affecting the mRNA levels of known sialyltransferases [204].

Treatment of HCT15 colon cancer cells with the demethylating drug 5-azacytidine (5-AZA) activates ST3GAL6 and expression of sLe ${ }^{\mathrm{x}}$ on MUC1 [84], while in prostate cancer cells, androgens induce transcriptional activation of ST3GAL2 through demethylation of its promoter [205].

5.2. How the expression of sialylated glycans on the cell membrane signals to cell interior (outside-in signaling)

The lipid rafts are cholesterol-rich membrane microdomains in which growth factor receptors, integrins and gangliosides coexist, favoring their interactions. The sialylation of plasma membrane glycoproteins, including integrins and growth factor receptors, modulates their activity and consequently the origin of the signaling pathways toward the nucleus (outside-in signaling). In addition, the activity of these receptors can be indirectly modulated by gangliosides. Examples of these mechanisms, depicted in Fig. 4, are described below.

c-Met is the receptor of the hepatocyte growth factor (also known as scatter factor) and is crucial for cancer cell motility and metastasis [206]. In a breast cancer cell line, the constitutive expression of ST8SIA1 and of gangliosides GD3 and GD2 results in proliferation in the absence of serum $[161,162]$ because of the constitutive activation of c-Met [160] and in the stimulation of MAPK and PIP3 signaling [160]. On the other hand, interaction of c-Met with monosialogangliosides GM3 and GM2 resulted in inhibition of its signaling and of cell motility [207-209]. c-Met activation can also be induced by the ST3GAL4induced expression of sLe ${ }^{\mathrm{x}}$, leading to phosphorylation of FAK and Src proteins [70]. Thus, the activation of c-Met signaling is the common downstream effect of the expression of different sialyltransferases.

GD3 can also stimulate cancer cell growth by direct interaction with cell signal transducers located on the internal side of the plasma membrane. GD3 promotes the association between FAK and p130 [210,211], enhancing signaling $[212,213]$ because of a stronger involvement of the Src kinase family member Yes which, in GD3-expressing cells, localizes in raft domains even before serum treatment [163]. The negative effect of ganglioside GM3 on the cell growth and on the activity of growth factor receptors has long been known [214,215]. A large body of data points to the interaction between GM3 and the ERBB membrane receptors family [216]. GM3 interacts with the GlcNAc termini of N-linked chains of ERBB1 (EGF receptor, EGFR), inhibiting its ligand-dependent activation [217-220], while the interaction of GM3 with the EGFR/ ERBB2 heterodimer induces its retention in lipid rafts in a phosphorylated form [221-223]. The expression of ST3GAL5 and of GM3 in non small cell lung cancer results in an increased number of EGFR molecules and increased sensitivity to the EGFR-tyrosine kinase gefitinib [224]. It has been proposed that the GM3-mediated inhibition of EGFR signaling is due to the inhibitory activity of protein kinase C- $\alpha$ on EGFR [225]. On the other hand, normal human fibroblasts not expressing ST3GAL5 
exhibit an over $90 \%$ reduction of the ganglioside content and a concomitant strong inhibition of EGFR signaling [226]. GM3 inhibits the proangiogenic activity of VEGF [152] through direct interaction with the VEGFR-2 receptor [227]. Apart from ganglioside contribution, glycosylation of EGFR can directly modulate its activity. In a lung cancer model, sialylation and fucosylation of EGFR resulted in a reduced, rather than increased, tendency to receptor dimerization and phosphorylation after EGF binding [228]. Consistently, in a colon cancer cell line, inhibition of ST6GAL1 resulted in increased growth and EGFR signaling upon EGF binding and increased sensitivity to the EGFR inhibitor gefitinib [183]. An opposite effect was displayed by ST3GAL1, whose expression enhanced gefitinib sensitivity [224]. However, $\alpha 2,6$-sialylation can also indirectly stimulate ERBB2/ERBB3 signaling. In fact, inhibition of ST6GAL1 by miR-199a reduced sialylation and the expression of a tumor suppressor which inhibits ERBB2/ERBB3 signaling [229].

Integrins are heterodimeric membrane glycoproteins mainly involved in binding to extracellular matrix components. After binding, integrins form focal adhesion complexes, activating signal transduction pathways downstream of growth factor receptors (Fig. 4). The integrin/ growth factor receptor crosstalk provides the cells with environmental signals necessary for proliferation [230,231]. The ST6GAL1-mediated sialylation of integrin $\beta 1$-chains reinforces the integrin-based signal transduction, as shown by increased binding of talin [134] and phosphorylation of focal adhesion kinase [144] and provides a survival signal through activation of paxillin/Akt [190]. Integrin function can also be modulated by interactions with the sugar portions of gangliosides. In fact, gangliosides GD3 and GT1b inhibit the binding of $\alpha 5 \beta 1$ integrin to fibronectin by direct binding of their carbohydrate portion with that of integrin $\alpha 5$ subunit [159] while GM3, in association with tetraspanin and CD9 interacts with $\beta 1$ integrins and inhibits cell motility [232,233].

Induction of tumor angiogenesis is mainly regulated by VEGFmediated stimulation of VEGF receptors. Inhibition of this interaction by the anti-VEGF-A monoclonal antibody bavacizumab is a widely used anti-cancer therapy. However, the existence of a glycosylationdependent, VEGF-independent mechanism of VEGFR stimulation, which can be at the basis of bevacizumab resistance has been recently described $[146,147]$. According to this mechanisms, in the tumor hypoxic conditions exacerbated by anti angiogenic treatment, ST6GAL1 was down-regulated, while N-acetylglucosaminyltransferase-V (MGAT5, responsible for $\beta 1,6$-branching) was up-regulated. The coordinate modulation of the two enzymes leads to a remodeling of the $\mathrm{N}$-linked chains of VEGFR2 which favors its binding by galectin-1 which, in turn, results in VEGFR signaling in the absence of its ligand. Thus, the ST6GAL1mediated sialylation of VEGF receptors exerts a key role in preventing angiogenesis and tumor progression [146,147].

$\mathrm{N}-\mathrm{CAM}$ provides another example of a cell adhesion molecule which modulates intracellular signaling through its PSA chains. Removal of PSA from N-CAM of neuroblastoma cells activates extracellular signalregulated kinase (ERK), leading to reduced proliferation and neuronal differentiation [234].

\subsection{Inside-out/outside-in loops}

Examples of positive or negative inside-out/outside-in loops are provided in Fig. 5. In the positive loop shown in A, a Ras mutation activates ST6GAL1, leading to $\alpha 2,6$-sialylation of $\beta 1$ integrins, stronger binding to ECM and increased FAK signaling. In the negative loop shown in B, cell transformation by the viral oncogene v-jun inhibits sialyltransferase ST3GAL5 and ganglioside GM3 expression, resulting in increased growth rate and anchorage independent growth [150]. Forced expression of ST3GAL5 results in the normalization of the transformed phenotype [150]. These data provide proof of the principle that aberrant oncogene expression results often in a deranged glycosylation pattern (inside-out), which in turn, modifies the gene expression of cancer cells (outside-in).

\section{Concluding remarks}

Glycosylation, among other postransductional modifications, is increasingly appreciated as a tool through which nature modifies the functional properties of the molecules without the need to alter the genetic code. In this review we have reported the alterations of significant sialylated structures and/or the level of expression of their cognate sialyltransferases, finding not always consistent results. This may depend on the fact that in many studies the level of glycosyltransferase expression was inferred from that of the corresponding RNA, although it is known that the RNA/protein quantitative relationship could be poor. Moreover, multiple mechanisms contribute to determine the actual level of a sialylated structure, including masking by substituents, competition between glycosyltransferases and role of sialidases. Amplification loops fueled by sialylated molecules which we discuss in this review are reminiscent of other amplification loops described in tumors, like that originated by Src, ErbB2 and PEAK1, recently described in pancreatic cancer [235]. The self-fueling loops where aberrant sialylated structures sustain cancer growth make sialyltransferases and/or their products attractive targets for innovative therapeutic treatments. However, based on experimental evidences, the use of sialyltransferase inhibitors or sialidases appears not sufficiently specific for clinical application, at the moment. More detailed knowledge of the mechanisms linking sialylation and cellular transformation, which is necessary to warrant the success of therapeutic approaches, will be the focus of future investigations.

\section{Acknowledgements}

Research was supported by grants from the University of Bologna and Pallotti Legacy for Cancer Research to F.D. and the University of Insubria to M.T. We thank Dr. C.M. Betts for the critical reading of the manuscript.

\section{References}

[1] Y. Li, X. Chen, Sialic acid metabolism and sialyltransferases: natural functions and applications, Appl. Microbiol. Biotechnol. 94 (2012) 887-905.

[2] A. Varki, P. Gagneux, Multifarious roles of sialic acids in immunity, Ann. N. Y. Acad. Sci. 1253 (2012) 16-36.

[3] N.M. Varki, E. Strobert, E.J. Dick, K. Benirschke, A. Varki, Biomedical differences between human and nonhuman hominids: potential roles for uniquely human aspects of sialic acid biology, Annu. Rev. Pathol. 6 (2011) 365-393.

[4] A. Harduin-Lepers, V. Vallejo-Ruiz, M. Krzewinski-Recchi, B. Samyn-Petit, S. Julien, P. Delannoy, The human sialyltransferase family, Biochimie 83 (2001) 727-737.

[5] F. Dall'Olio, M. Chiricolo, Sialyltransferases in cancer, Glycoconj. J. 18 (2001) 841-850.

[6] A. Harduin-Lepers, M.A. Krzewinski-Recchi, F. Colomb, F. Foulquier, S. GrouxDegroote, P. Delannoy, Sialyltransferases functions in cancers, Front. Biosci. (Elite Ed.) 4 (2012) 499-515.

[7] A.M. Cohen, D. Allalouf, M. Djaldetti, K. Weigl, N. Lehrer, H. Levinsky, Sialyltransferase activity in plasma cells of multiple myeloma, Eur. J. Haematol. 43 (1989) 191-194.

[8] C. Dwivedi, M. Dixit, R.E. Hardy, Plasma sialyltransferase as a tumor marker, Cancer Detect. Prev. 11 (1988) 191-196.

[9] U. Ganzinger, E. Deutsch, Serum sialyltransferase levels as a parameter in the diagnosis and follow-up of gastrointestinal tumors, Cancer Res. 40 (1980) 1300-1304.

[10] A.L. Shen, M.D. Chou, C.W. Chi, L.S. Lee, Alterations in serum sialyltransferase activities in patients with brain tumors, Surg. Neurol. 22 (1984) 509-514.

[11] M.J. Schultz, A.F. Swindall, S.L. Bellis, Regulation of the metastatic cell phenotype by sialylated glycans, Cancer Metastasis Rev. 31 (2012) 501-518.

[12] J.G. Collard, J.F. Schijven, A. Bikker, G. La Riviere, J.G. Bolscher, E. Roos, Cell surface sialic acid and the invasive and metastatic potential of T-cell hybridomas, Cancer Res. 46 (1986) 3521-3527.

[13] J. Dennis, C. Waller, R. Timpl, V. Schirrmacher, Surface sialic acid reduces attachment of metastatic tumour cells to collagen type IV and fibronectin, Nature 300 (1982) 274-276.

[14] J. Morgenthaler, W. Kemmner, R. Brossmer, Sialic acid dependent cell adhesion to collagen IV correlates with in vivo tumorigenicity of the human colon carcinoma sublines HCT116, HCT116a and HCT116b, Biochem. Biophys. Res. Commun. 171 (1990) 860-866.

[15] I. Kijima-Suda, Y. Miyamoto, S. Toyoshima, M. Itoh, T. Osawa, Inhibition of experimental pulmonary metastasis of mouse colon adenocarcinoma 26 sublines by a sialic acid:nucleoside conjugate having sialyltransferase inhibiting activity, Cancer Res. 46 (1986) 858-862. 
[16] I. Kijima-Suda, T. Miyazawa, M. Itoh, S. Toyoshima, T. Osawa, Possible mechanism of inhibition of experimental pulmonary metastasis of mouse colon adenocarcinoma 26 sublines by a sialic acid: nucleoside conjugate, Cancer Res. 48 (1988) 3728-3732.

[17] H.E. Wagner, P. Thomas, B.C. Wolf, A. Rapoza, G. Steele Jr., Inhibition of sialic acid incorporation prevents hepatic metastases, Arch. Surg. 125 (1990) 351-354.

[18] T. Miyagi, K. Sato, K. Hata, S. Taniguchi, Metastatic potential of transformed rat $3 Y 1$ cell lines is inversely correlated with lysosomal-type sialidase activity, FEBS Lett. 349 (1994) 255-259.

[19] N.B. Drinnan, J. Halliday, T. Ramsdale, Inhibitors of sialyltransferases: potential roles in tumor growth and metastasis, Mini-Rev. Med. Chem. 3 (2003) 501-517.

[20] B.E. Harvey, C.A. Toth, H.E. Wagner, G.D. Steele Jr., P. Thomas, Sialyltransferase activity and hepatic tumor growth in a nude mouse model of colorectal cancer metastases, Cancer Res. 52 (1992) 1775-1779.

[21] C. Bull, T.J. Boltje, M. Wassink, A.M. de Graaf, F.L. van Delft, M.H. den Brok, G.J. Adema, Targeting aberrant sialylation in cancer cells using a fluorinated sialic acid analog impairs adhesion, migration, and in vivo tumor growth, Mol. Cancer Ther. 12 (2013) 1935-1946.

[22] J.Y. Chen, Y.A. Tang, S.M. Huang, H.F. Juan, L.W. Wu, Y.C. Sun, S.C. Wang, K.W. Wu, G. Balraj, T.T. Chang, W.S. Li, H.C. Cheng, Y.C. Wang, A novel sialyltransferase inhibitor suppresses FAK/paxillin signaling and cancer angiogenesis and metastasis pathways, Cancer Res. 71 (2011) 473-483.

[23] C.H. Chiang, C.H. Wang, H.C. Chang, S.V. More, W.S. Li, W.C. Hung, A novel sialyltransferase inhibitor AL10 suppresses invasion and metastasis of lung cancer cells by inhibiting integrin-mediated signaling, J. Cell. Physiol. 223 (2010) 492-499.

[24] C.C. Hsu, T.W. Lin, W.W. Chang, C.Y. Wu, W.H. Lo, P.H. Wang, Y.C. Tsai, Soyasaponin-I-modified invasive behavior of cancer by changing cell surface sialic acids, Gynecol. Oncol. 96 (2005) 415-422.

[25] W.W. Chang, C.Y. Yu, T.W. Lin, P.H. Wang, Y.C. Tsai, Soyasaponin I decreases the expression of alpha2,3-linked sialic acid on the cell surface and suppresses the metastatic potential of B16F10 melanoma cells, Biochem. Biophys. Res. Commun. 341 (2006) 614-619.

[26] I. Brockhausen, Pathways of O-glycan biosynthesis in cancer cells, Biochim. Biophys. Acta 1473 (1999) 67-95.

[27] F.G. Hanisch, S.E. Baldus, The Thomsen-Friedenreich (TF) antigen: a critical review on the structural, biosynthetic and histochemical aspects of a pancarcinoma-associated antigen, Histol. Histopathol. 12 (1997) 263-281.

[28] J.M. Burchell, A. Mungul, J. Taylor-Papadimitriou, O-linked glycosylation in the mammary gland: changes that occur during malignancy, J. Mammary Gland Biol. Neoplasia 6 (2001) 355-364.

[29] A. Cazet, S. Julien, M. Bobowski, J. Burchell, P. Delannoy, Tumour-associated carbohydrate antigens in breast cancer, Breast Cancer Res. 12 (2010) 204

[30] J. Burchell, R. Poulsom, A. Hanby, C. Whitehouse, L. Cooper, H. Clausen, D. Miles, J. Taylor-Papadimitriou, An $\alpha 2,3$ sialyltransferase (ST3Gal I) is elevated in primary breast carcinomas, Glycobiology 9 (1999) 1307-1311.

[31] N.T. Marcos, A. Cruz, F. Silva, R. Almeida, L. David, U. Mandel, H. Clausen, S. Mensdorff-Pouilly, C.A. Reis, Polypeptide GalNAc-transferases, ST6GalNActransferase I, and ST3Gal- transferase I expression in gastric carcinoma cell lines, J. Histochem. Cytochem. 51 (2003) 761-771.

[32] C. Whitehouse, J. Burchell, S. Gschmeissner, I. Brockhausen, K.O. Lloyd, J. TaylorPapadimitriou, A transfected sialyltransferase that is elevated in breast cancer and localizes to the medial/trans-Golgi apparatus inhibits the development of core-2-based O-glycans, J. Cell Biol. 137 (1997) 1229-1241.

[33] D. Sproviero, S. Julien, B. Burford, J. Taylor-Papadimitriou, J.M. Burchell, Cyclooxygenase-2 enzyme induces the expression of the $\alpha$-2,3-sialyltransferase3 (ST3Gal-I) in breast cancer, J. Biol. Chem. 287 (2012) 44490-44497.

[34] T. Koike, N. Kimura, K. Miyazaki, T. Yabuta, K. Kumamoto, S. Takenoshita, J. Chen, M. Kobayashi, M. Hosokawa, A. Taniguchi, T. Kojima, N. Ishida, M. Kawakita, H. Yamamoto, H. Takematsu, A. Suzuki, Y. Kozutsumi, R. Kannagi, Hypoxia induces adhesion molecules on cancer cells: a missing link between Warburg effect and induction of selectin-ligand carbohydrates, Proc. Natl. Acad. Sci. U. S. A. 101 (2004) 8132-8137.

[35] M.A. Hollingsworth, B.J. Swanson, Mucins in cancer: protection and control of the cell surface, Nat. Rev. Cancer 4 (2004) 45-60.

[36] A. Solatycka, T. Owczarek, F. Piller, V. Piller, B. Pula, L. Wojciech, M. PodhorskaOkolow, P. Dziegiel, M. Ugorski, MUC1 in human and murine mammary carcinoma cells decreases the expression of core $2 \beta 1,6-\mathrm{N}$-acetylglucosaminyltransferase and $\beta$-galactoside $\alpha 2,3$-sialyltransferase, Glycobiology 22 (2012) 1042-1054.

[37] G. Picco, S. Julien, I. Brockhausen, R. Beatson, A. Antonopoulos, S. Haslam, U. Mandel, A. Dell, S. Pinder, J. Taylor-Papadimitriou, J. Burchell, Over-expression of ST3Gal-I promotes mammary tumorigenesis, Glycobiology 20 (2010) 1241-1250.

[38] S. Itzkowitz, Carbohydrate changes in colon carcinoma, APMIS Suppl. 27 (1992) $173-180$.

[39] F. Schneider, W. Kemmner, W. Haensch, G. Franke, S. Gretschel, U. Karsten, P.M. Schlag, Overexpression of sialyltransferase CMP-sialic acid:Galß1,3GalNAc-R $\alpha 6$ sialyltransferase is related to poor patient survival in human colorectal carcinomas, Cancer Res. 61 (2001) 4605-4611.

[40] P.A. Videira, M. Correia, N. Malagolini, H.J. Crespo, D. Ligeiro, F.M. Calais, H. Trindade, F. Dall'Olio, ST3Gal.I sialyltransferase relevance in bladder cancer tissues and cell lines, BMC Cancer 9 (2009) 357.

[41] T. Conze, A.S. Carvalho, U. Landegren, R. Almeida, C.A. Reis, L. David, O. Soderberg, MUC2 mucin is a major carrier of the cancer-associated sialyl-Tn antigen in intestinal metaplasia and gastric carcinomas, Glycobiology 20 (2010) 199-206.

[42] M. Sasaki, T. Yamato, Y. Nakanuma, Expression of sialyl-Tn, Tn and T antigens in primary liver cancer, Pathol. Int. 49 (1999) 325-331.
[43] S. Ohno, Y. Ohno, H. Nakada, N. Suzuki, G. Soma, M. Inoue, Expression of Tn and sialyl-Tn antigens in endometrial cancer: its relationship with tumor-produced cyclooxygenase-2, tumor-infiltrated lymphocytes and patient prognosis, Anticancer Res. 26 (2006) 4047-4053.

[44] J.A. Ferreira, P.A. Videira, L. Lima, S. Pereira, M. Silva, M. Carrascal, P.F. Severino, E. Fernandes, A. Almeida, C. Costa, R. Vitorino, T. Amaro, M.J. Oliveira, C.A. Reis, F. Dall'Olio, F. Amado, L.L. Santos, Overexpression of tumour-associated carbohydrate antigen sialyl-Tn in advanced bladder tumours, Mol. Oncol. 7 (2013) 719-731.

[45] L. Lima, P.F. Severino, M. Silva, A. Miranda, A. Tavares, S. Pereira, E. Fernandes, R. Cruz, T. Amaro, C.A. Reis, F. Dall'Olio, F. Amado, P.A. Videira, L. Santos, J.A. Ferreira, Response of high-risk of recurrence/progression bladder tumours expressing sialyl-Tn and sialyl-6-T to BCG immunotherapy, Br. J. Cancer 109 (2013) 2106-2114.

[46] M. Leivonen, S. Nordling, J. Lundin, K. von Boguslawski, C. Haglund, STn and prognosis in breast cancer, Oncology 61 (2001) 299-305.

[47] N.T. Marcos, S. Pinho, C. Grandela, A. Cruz, B. Samyn-Petit, A. Harduin-Lepers, R. Almeida, F. Silva, V. Morais, J. Costa, J. Kihlberg, H. Clausen, C.A. Reis, Role of the human ST6GalNAc-I and ST6GalNAc-II in the synthesis of the cancer-associated sialyl-Tn antigen, Cancer Res. 64 (2004) 7050-7057.

[48] R. Sewell, M. Backstrom, M. Dalziel, S. Gschmeissner, H. Karlsson, T. Noll, J. Gatgens, H. Clausen, G.C. Hansson, J. Burchell, J. Taylor-Papadimitriou, The ST6GalNAc-I sialyltransferase localizes throughout the Golgi and is responsible for the synthesis of the tumor-associated sialyl-Tn O-glycan in human breast cancer, J. Biol. Chem. 281 (2006) 3586-3594.

[49] B. Mann, E. Klussmann, V. Vandamme-Feldhaus, M. Iwersen, M.L. Hanski, E.O Riecken, H.J. Buhr, R. Schauer, Y.S. Kim, C. Hanski, Low O-acetylation of sialylLe(x) contributes to its overexpression in colon carcinoma metastases, Int. J. Cancer 72 (1997) 258-264.

[50] I. Brockhausen, J. Yang, N. Dickinson, S. Ogata, S.H. Itzkowitz, Enzymatic basis for sialyl-Tn expression in human colon cancer cells, Glycoconj. J. 15 (1998) 595-603.

[51] H. Barrow, B. Tam, C.A. Duckworth, J.M. Rhodes, L.G. Yu, Suppression of core 1 Galtransferase is associated with reduction of TF and reciprocal increase of Tn, sialylTn and core 3 glycans in human colon cancer cells, PLoS ONE 8 (2013) e59792.

[52] C. Vazquez-Martin, E. Cuevas, E. Gil-Martin, A. Fernandez-Briera, Correlation analysis between tumor-associated antigen sialyl-Tn expression and ST6GalNAc I activity in human colon adenocarcinoma, Oncology 67 (2004) 159-165.

[53] M. Clement, J. Rocher, G. Loirand, J. Le Pendu, Expression of sialyl-Tn epitopes on $\beta 1$ integrin alters epithelial cell phenotype, proliferation and haptotaxis, J. Cell Sci. 117 (2004) 5059-5069.

[54] S. Julien, M.A. Krzewinski-Recchi, A. Harduin-Lepers, V. Gouyer, G. Huet, X. B. Le, P. Delannoy, Expression of sialyl-Tn antigen in breast cancer cells transfected with the human CMP-Neu5Ac: GalNAc alpha2,6-sialyltransferase (ST6GalNac I) cDNA, Glycoconj. J. 18 (2001) 883-893.

[55] S. Julien, C. Lagadec, M.A. Krzewinski-Recchi, G. Courtand, X. B. Le, P. Delannoy, Stable expression of sialyl-Tn antigen in T47-D cells induces a decrease of cell adhesion and an increase of cell migration, Breast Cancer Res. Treat. 90 (2005) 77-84.

[56] S. Julien, E. Adriaenssens, K. Ottenberg, A. Furlan, G. Courtand, A.S. VercoutterEdouart, F.G. Hanisch, P. Delannoy, X. B. Le, ST6GalNAc I expression in MDA-MB231 breast cancer cells greatly modifies their O-glycosylation pattern and enhances their tumourigenicity, Glycobiology 16 (2006) 54-64.

[57] H. Ozaki, H. Matsuzaki, H. Ando, H. Kaji, H. Nakanishi, Y. Ikehara, H. Narimatsu, Enhancement of metastatic ability by ectopic expression of ST6GalNAcI on a gastric cancer cell line in a mouse model, Clin. Exp. Metastasis 29 (2012) 229-238.

[58] S. Pinho, N.T. Marcos, B. Ferreira, A.S. Carvalho, M.J. Oliveira, F. Santos-Silva, A. Harduin-Lepers, C.A. Reis, Biological significance of cancer-associated sialyl-Tn antigen: modulation of malignant phenotype in gastric carcinoma cells, Cancer Lett. 249 (2007) 157-170.

[59] S. Pillai, I.A. Netravali, A. Cariappa, H. Mattoo, Siglecs and immune regulation, Annu. Rev. Immunol. 30 (2012) 357-392.

[60] R. Takamiya, K. Ohtsubo, S. Takamatsu, N. Taniguchi, T. Angata, The interaction between Siglec-15 and tumor-associated sialyl-Tn antigen enhances TGF-beta secretion from monocytes/macrophages through the DAP12-Syk pathway, Glycobiology 23 (2013) 178-187.

[61] M.A. Carrascal, P.F. Severino, C.M. Guadalupe, M. Silva, J.A. Ferreira, F. Calais, H Quinto, C. Pen, D. Ligeiro, L.L. Santos, F. Dall'Olio, P.A. Videira, Sialyl Tnexpressing bladder cancer cells induce a tolerogenic phenotype in innate and adaptive immune cells, Mol. Oncol. 8 (2014) 753-765.

[62] N. Murugaesu, M. Iravani, A. van Weverwijk, A. Ivetic, D.A. Johnson, A Antonopoulos, A. Fearns, M. Jamal-Hanjani, D. Sims, K. Fenwick, C. Mitsopoulos, Q. Gao, N. Orr, M. Zvelebil, S.M. Haslam, A. Dell, H. Yarwood, C.J. Lord, A Ashworth, C.M. Isacke, An in vivo functional screen identifies ST6GalNAc2 sialyltransferase as a breast cancer metastasis suppressor, Cancer Discov. 4 (2014) 304-317.

[63] A. Cazet, S. Julien, M. Bobowski, M.A. Krzewinski-Recchi, A. Harduin-Lepers, S. Groux-Degroote, P. Delannoy, Consequences of the expression of sialylated antigens in breast cancer, Carbohydr. Res. 345 (2010) 1377-1383.

[64] C. Foxall, S.R. Watson, D. Dowbenko, C. Fennie, L.A. Lasky, M. Kiso, A. Hasegawa, D. Asa, B.K. Brandley, The three members of the selectin receptor family recognize a common carbohydrate epitope, the sialyl Lewis ${ }^{\mathrm{x}}$ oligosaccharide, J. Cell Biol. 117 (1992) 895-902.

[65] S. Nakamori, M. Kameyama, S. Imaoka, H. Furukawa, O. Ishikawa, Y. Sasaki, Y Izumi, T. Irimura, Involvement of carbohydrate antigen sialyl Lewis ${ }^{\mathrm{x}}$ in colorectal cancer metastasis, Dis. Colon Rectum 40 (1997) 420-431.

[66] L. Terraneo, L. Avagliano, A. Caretti, P. Bianciardi, D. Tosi, G.P. Bulfamante, M Samaja, M. Trinchera, Expression of carbohydrate-antigen sialyl-Lewis a on colon cancer cells promotes xenograft growth and angiogenesis in nude mice, Int. J. Biochem. Cell Biol. 45 (2013) 2796-2800. 
[67] A.S. Carvalho, A. Harduin-Lepers, A. Magalhaes, E. Machado, N. Mendes, L.T. Costa, R. Matthiesen, R. Almeida, J. Costa, C.A. Reis, Differential expression of $\alpha-2,3-$ sialyltransferases and $\alpha-1,3 / 4$-fucosyltransferases regulates the levels of sialyl Lewis a and sialyl Lewis x in gastrointestinal carcinoma cells, Int. J. Biochem. Cell Biol. 42 (2010) 80-89.

[68] M. Perez-Garay, B. Arteta, L. Pages, R. De Llorens, C. de Bolos, F. Vidal-Vanaclocha, R Peracaula, $\alpha 2,3-$ Sialyltransferase ST3Gal III modulates pancreatic cancer cell motility and adhesion in vitro and enhances its metastatic potential in vivo, PLoS ONE 5 (2010) e12524

[69] C.J. Dimitroff, P. Pera, F. Dall'Olio, K.L. Matta, E.V. Chandrasekaran, J.T. Lau, R.J. Bernacki, Cell surface n-acetylneuraminic acid $\alpha 2,3$-galactoside-dependent intercellular adhesion of human colon cancer cells, Biochem. Biophys. Res. Commun. 256 (1999) 631-636.

[70] C. Gomes, H. Osorio, M.T. Pinto, D. Campos, M.J. Oliveira, C.A. Reis, Expression of ST3GAL4 leads to SLe ${ }^{\mathrm{x}}$ expression and induces c-Met activation and an invasive phenotype in gastric carcinoma cells, PLoS ONE 8 (2013) e66737.

[71] M. Perez-Garay, B. Arteta, E. Llop, L. Cobler, L. Pages, R. Ortiz, M.J. Ferri, C. de Bolos, J. Figueras, R. De Llorens, F. Vidal-Vanaclocha, R. Peracaula, $\alpha 2,3$-Sialyltransferase ST3Gal IV promotes migration and metastasis in pancreatic adenocarcinoma cells and tends to be highly expressed in pancreatic adenocarcinoma tissues, Int. J. Biochem. Cell Biol. 45 (2013) 1748-1757.

[72] F. Colomb, M.A. Krzewinski-Recchi, F. El Machhour, E. Mensier, S. Jaillard, A Steenackers, A. Harduin-Lepers, J.J. Lafitte, P. Delannoy, S. Groux-Degroote, TNF regulates sialyl-Lewisx and 6-sulfo-sialyl-Lewisx expression in human lung through up-regulation of ST3GAL4 transcript isoform BX, Biochimie 94 (2012) 2045-2053.

[73] K.M. Hiller, J.P. Mayben, K.M. Bendt, G.A. Manousos, K. Senger, H.S. Cameron, B.W Weston, Transfection of $\alpha 1,3$ fucosyltransferase antisense sequences impairs the proliferative and tumorigenic ability of human colon carcinoma cells, Mol Carcinog. 27 (2000) 280-288.

[74] B.W. Weston, K.M. Hiller, J.P. Mayben, G.A. Manousos, K.M. Bendt, R. Liu, J.C. Cusack Jr., Expression of human $\alpha 1,3$ fucosyltransferase antisense sequences inhibits selectin-mediated adhesion and liver metastasis of colon carcinoma cells, Cancer Res. 59 (1999) 2127-2135.

[75] M. Trinchera, N. Malagolini, M. Chiricolo, D. Santini, F. Minni, A. Caretti, F. Dall'Olio, The biosynthesis of the selectin-ligand sialyl Lewis $\mathrm{x}$ in colorectal cancer tissues is regulated by fucosyltransferase VI and can be inhibited by an RNA interferencebased approach, Int. J. Biochem. Cell Biol. 43 (2011) 130-139.

[76] T. Kudo, Y. Ikehara, A. Togayachi, K. Morozumi, M. Watanabe, M. Nakamura, S. Nishihara, H. Narimatsu, Up-regulation of a set of glycosyltransferase genes in human colorectal cancer, Lab. Investig. 78 (1998) 797-811.

[77] T. Petretti, W. Kemmner, B. Schulze, P.M. Schlag, Altered mRNA expression of glycosyltransferases in human colorectal carcinomas and liver metastases, Gut 46 (2000) 359-366.

[78] H. Ito, N. Hiraiwa, M. Sawada-Kasugai, S. Akamatsu, T. Tachikawa, Y. Kasai, S Akiyama, K. Ito, H. Takagi, R. Kannagi, Altered mRNA expression of specific molecular species of fucosyl- and sialyl-transferases in human colorectal cancer tissues, Int. J. Cancer 71 (1997) 556-564.

[79] F. Dall'Olio, N. Malagolini, M. Trinchera, M. Chiricolo, Mechanisms of cancerassociated glycosylation changes, Front. Biosci. 17 (2012) 670-699.

[80] F. Dall'Olio, N. Malagolini, M. Chiricolo, Glycosylation in cancer, Specialist Periodical Reports Carbohydrate Chemistry, 37, 2012, pp. 21-56.

[81] F. Colomb, O. Vidal, M. Bobowski, M.A. Krzewinski-Recchi, A. Harduin-Lepers, E. Mensier, S. Jaillard, J.J. Lafitte, P. Delannoy, S. Groux-Degroote, TNF induces the expression of the sialyltransferase ST3Gal IV in human bronchial mucosa via MSK1/2 protein kinases and increases FliD/sialyl-Lewisx-mediated adhesion of Pseudomonas aeruginosa, Biochem. J. 457 (2014) 79-87.

[82] P. Radhakrishnan, V. Chachadi, M.F. Lin, R. Singh, R. Kannagi, P.W. Cheng, TNFo enhances the motility and invasiveness of prostatic cancer cells by stimulating the expression of selective glycosyl- and sulfotransferase genes involved in the synthesis of selectin ligands, Biochem. Biophys. Res. Commun. 409 (2011) 436-441.

[83] K. Sakuma, M. Aoki, R. Kannagi, Transcription factors c-Myc and CDX2 mediate E-selectin ligand expression in colon cancer cells undergoing EGF/bFGFinduced epithelial-mesenchymal transition, Proc. Natl. Acad. Sci. U. S. A. 109 (2012) 7776-7781.

[84] V.B. Chachadi, H. Cheng, D. Klinkebiel, J.K. Christman, P.W. Cheng, 5-Aza-2'deoxycytidine increases sialyl Lewis X on MUC1 by stimulating $\beta$-galactoside: $\alpha 2,3$-sialyltransferase 6 gene, Int. J. Biochem. Cell Biol. 43 (2011) 586-593.

[85] M.A. Recchi, M. Hebbar, L. Hornez, A. Harduin-Lepers, J.P. Peyrat, P. Delannoy, Multiplex reverse transcription polymerase chain reaction assessment of sialyltransferase expression in human breast cancer, Cancer Res. 58 (1998) 4066-4070.

[86] M. Hebbar, M.A. Krzewinski-Recchi, L. Hornez, A. Verdiere, A. Harduin-Lepers, J Bonneterre, P. Delannoy, J.P. Peyrat, Prognostic value of tumoral sialyltransferase expression and circulating E-selectin concentrations in node-negative breast cancer patients, Int. J. Biol. Markers 18 (2003) 116-122.

[87] S. Julien, A. Ivetic, A. Grigoriadis, D. Qize, B. Burford, D. Sproviero, G. Picco, C. Gillett, S.L. Papp, L. Schaffer, A. Tutt, J. Taylor-Papadimitriou, S.E. Pinder, J.M. Burchell, Selectin ligand sialyl-Lewis $\mathrm{x}$ antigen drives metastasis of hormone-dependent breast cancers, Cancer Res. 71 (2011) 7683-7693.

[88] J. Finne, U. Finne, H. Deagostini-Bazin, C. Goridis, Occurrence of alpha 2-8 linked polysialosyl units in a neural cell adhesion molecule, Biochem. Biophys. Res. Commun. 112 (1983) 482-487.

[89] U. Rutishauser, Polysialic acid in the plasticity of the developing and adult vertebrate nervous system, Nat. Rev. Neurosci. 9 (2008) 26-35.

[90] M. Muhlenhoff, M. Eckhardt, R. Gerardy-Schahn, Polysialic acid: three-dimensiona structure, biosynthesis and function, Curr. Opin. Struct. Biol. 8 (1998) 558-564.
[91] C.P. Johnson, I. Fujimoto, U. Rutishauser, D.E. Leckband, Direct evidence that neural cell adhesion molecule (NCAM) polysialylation increases intermembrane repulsion and abrogates adhesion, J. Biol. Chem. 280 (2005) 137-145.

[92] S.C. Schreiber, K. Giehl, C. Kastilan, C. Hasel, M. Muhlenhoff, G. Adler, D. Wedlich, A. Menke, Polysialylated NCAM represses E-cadherin-mediated cell-cell adhesion in pancreatic tumor cells, Gastroenterology 134 (2008) 1555-1566.

[93] B.D. Livingston, J.C. Paulson, Polymerase chain reaction cloning of a developmentally regulated member of the sialyltransferase gene family, J. Biol. Chem. 268 (1993) 11504-11507.

[94] M. Eckhardt, M. Muhlenhoff, A. Bethe, J. Koopman, M. Frosch, R. Gerardy-Schahn, Molecular characterization of eukaryotic polysialyltransferase-1, Nature 373 (1995) 715-718.

[95] I. Oltmann-Norden, S.P. Galuska, H. Hildebrandt, R. Geyer, R. Gerardy-Schahn, H. Geyer, M. Muhlenhoff, Impact of the polysialyltransferases ST8SiaII and ST8SiaIV on polysialic acid synthesis during postnatal mouse brain development, J. Biol. Chem. 283 (2008) 1463-1471.

[96] R.A. Falconer, R.J. Errington, S.D. Shnyder, P.J. Smith, L.H. Patterson, Polysialyltransferase: a new target in metastatic cancer, Curr. Cancer Drug Targets 12 (2012) 925-939.

[97] H. Hildebrandt, C. Becker, S. Gluer, H. Rosner, R. Gerardy-Schahn, H. Rahmann, Polysialic acid on the neural cell adhesion molecule correlates with expression of polysialyltransferases and promotes neuroblastoma cell growth, Cancer Res. 58 (1998) 779-784.

[98] F. Tanaka, Y. Otake, T. Nakagawa, Y. Kawano, R. Miyahara, M. Li, K. Yanagihara, J. Nakayama, I. Fujimoto, K. Ikenaka, H. Wada, Expression of polysialic acid and STX, a human polysialyltransferase, is correlated with tumor progression in nonsmall cell lung cancer, Cancer Res. 60 (2000) 3072-3080.

[99] B.D. Livingston, J.L. Jacobs, M.C. Glick, F.A. Troy, Extended polysialic acid chains (n greater than 55) in glycoproteins from human neuroblastoma cells, J. Biol. Chem. 263 (1988) 9443-9448.

[100] Y.M. Al Saraireh, M. Sutherland, B.R. Springett, F. Freiberger, M.G. Ribeiro, P.M. Loadman, R.J. Errington, P.J. Smith, M. Fukuda, R. Gerardy-Schahn, L.H. Patterson, S.D. Shnyder, R.A. Falconer, Pharmacological inhibition of polysialyltransferase ST8SiaII modulates tumour cell migration, PLoS ONE 8 (2013) e73366.

[101] J. Li, G. Dai, Y.B. Cheng, X. Qi, M.Y. Geng, Polysialylation promotes neural cell adhesion molecule-mediated cell migration in a fibroblast growth factor receptordependent manner, but independent of adhesion capability, Glycobiology 21 (2011) 1010-1018.

[102] M. Suzuki, M. Suzuki, J. Nakayama, A. Suzuki, K. Angata, S. Chen, K. Sakai, K. Hagihara, Y. Yamaguchi, M. Fukuda, Polysialic acid facilitates tumor invasion by glioma cells, Glycobiology 15 (2005) 887-894.

[103] U. Valentiner, M. Muhlenhoff, U. Lehmann, H. Hildebrandt, U. Schumacher, Expression of the neural cell adhesion molecule and polysialic acid in human neuroblastoma cell lines, Int. J. Oncol. 39 (2011) 417-424.

[104] T. Jimbo, J. Nakayama, K. Akahane, M. Fukuda, Effect of polysialic acid on the tumor xenografts implanted into nude mice, Int. J. Cancer 94 (2001) 192-199.

[105] K. Eggers, S. Werneburg, A. Schertzinger, M. Abeln, M. Schiff, M.A. Scharenberg, H. Burkhardt, M. Muhlenhoff, H. Hildebrandt, Polysialic acid controls NCAM signals at cell-cell contacts to regulate focal adhesion independent from FGF receptor activity, J. Cell Sci. 124 (2011) 3279-3291.

[106] R. Seidenfaden, R. Gerardy-Schahn, H. Hildebrandt, Control of NCAM polysialylation by the differential expression of polysialyltransferases ST8SiaII and ST8SiaIV, Eur. J. Cell Biol. 79 (2000) 680-688.

[107] I.Y. Cheung, A. Vickers, N.K. Cheung, Sialyltransferase STX (ST8SiaII): a novel molecular marker of metastatic neuroblastoma, Int. J. Cancer 119 (2006) 152-156.

[108] K. Bork, D. Gagiannis, A. Orthmann, W. Weidemann, M. Kontou, W. Reutter, R. Horstkorte, Experimental approaches to interfere with the polysialylation of the neural cell adhesion molecule in vitro and in vivo, J. Neurochem. 103 (Suppl. 1) (2007) 65-71.

[109] A.K. Perl, U. Dahl, P. Wilgenbus, H. Cremer, H. Semb, G. Christofori, Reduced expression of neural cell adhesion molecule induces metastatic dissemination of pancreatic beta tumor cells, Nat. Med. 5 (1999) 286-291.

[110] H. Sasaki, K. Yoshida, E. Ikeda, H. Asou, M. Inaba, M. Otani, T. Kawase, Expression of the neural cell adhesion molecule in astrocytic tumors: an inverse correlation with malignancy, Cancer 82 (1998) 1921-1931.

[111] M. Korja, A. Jokilammi, T.T. Salmi, H. Kalimo, T.T. Pelliniemi, J. Isola, I. Rantala, H. Haapasalo, J. Finne, Absence of polysialylated NCAM is an unfavorable prognostic phenotype for advanced stage neuroblastoma, BMC Cancer 9 (2009) 57.

[112] K. Yamashita, K. Fukushima, T. Sakiyama, F. Murata, M. Kuroki, Y. Matsuoka, Expression of Sia $\alpha 2 \rightarrow 6$ Gal $\alpha 1 \rightarrow 4$ GlcNAc residues on sugar chains of glycoproteins including carcinoembryonic antigens in human colon adenocarcinoma: applications of Trichosanthes japonica agglutinin I for early diagnosis, Cancer Res. 55 (1995) 1675-1679.

[113] V. Toma, C. Zuber, H.C. Winter, I.J. Goldstein, J. Roth, Application of a lectin from the mushroom Polysporus squamosus for the histochemical detection of the NeuAc $\alpha 2,6 \mathrm{Gal} \beta 1,4 \mathrm{Glc} / \mathrm{GlcNAc}$ sequence of N-linked oligosaccharides: a comparison with the Sambucus nigra lectin, Histochem. Cell Biol. 116 (2001) 183-193.

[114] H. Korekane, A. Matsumoto, F. Ota, T. Hasegawa, Y. Misonou, K. Shida, Y. Miyamoto, $\mathrm{N}$. Taniguchi, Involvement of ST6Gal I in the biosynthesis of a unique human colon cancer biomarker candidate, $\alpha 2,6$-sialylated blood group type $2 \mathrm{H}(\mathrm{ST} 2 \mathrm{H})$ antigen, J. Biochem. 148 (2010) 359-370.

[115] B.J. Bast, L.J. Zhou, G.J. Freeman, K.J. Colley, T.J. Ernst, J.M. Munro, T.F. Tedder, The HB-6, CDw75, and CD76 differentiation antigens are unique cell-surface carbohydrate determinants generated by the $\beta$-galactoside $\alpha$ 2,6-sialyltransferase, J. Cell Biol. 116 (1992) 423-435. 
[116] F. Dall'Olio, N. Malagolini, G. Di Stefano, F. Minni, D. Marrano, F. Serafini-Cessi, Increased CMP-NeuAc:GalB1,4GlcNAc-R $\alpha$ 2,6 sialyltransferase activity in human colorectal cancer tissues, Int. J. Cancer 44 (1989) 434-439.

[117] C. Costa-Nogueira, S. Villar-Portela, E. Cuevas, E. Gil-Martin, A. Fernandez-Briera, Synthesis and expression of CDw75 antigen in human colorectal cancer, BMC Cancer 9 (2009) 431.

[118] P. Gessner, S. Riedl, A. Quentmaier, W. Kemmner, Enhanced activity of CMPNeuAc:Gal $\beta$ 1-4GlcNAc: $\alpha$ 2,6-sialyltransferase in metastasizing human colorectal tumor tissue and serum of tumor patients, Cancer Lett. 75 (1993) 143-149.

[119] A. Gangopadhyay, S.P. Perera, P. Thomas, Differential expression of $\alpha 2,6-$ sialyltransferase in colon tumors recognized by a monoclonal antibody, Hybridoma 17 (1998) 117-123.

[120] F. Dall'Olio, The sialyl- $\alpha 2,6$-lactosaminyl-structure: biosynthesis and functional role, Glycoconj. J. 17 (2000) 669-676.

[121] M.J. Vierbuchen, W. Fruechtnicht, S. Brackrock, K.T. Krause, T.J. Zienkiewicz, Quantitative lectin-histochemical and immunohistochemical studies on the occurrence of $\alpha(2,3)$ - and $\alpha(2,6)$-linked sialic acid residues in colorectal carcinomas. Relation to clinicopathologic features, Cancer 76 (1995) 727-735.

[122] M. Lise, C. Belluco, S.P. Perera, R. Patel, P. Thomas, A. Ganguly, Clinical correlations of $\alpha 2,6$-sialyltransferase expression in colorectal cancer patients, Hybridoma 19 (2000) 281-286.

[123] J. Gebert, M. Kloor, J. Lee, M. Lohr, S. Andre, R. Wagner, J. Kopitz, H.J. Gabius, Colonic carcinogenesis along different genetic routes: glycophenotyping of tumor cases separated by microsatellite instability/stability, Histochem. Cell Biol. 138 (2012) 339-350.

[124] D. Pousset, V. Piller, N. Bureaud, M. Monsigny, F. Piller, Increased $\alpha 2,6$ sialylation of $\mathrm{N}$-glycans in a transgenic mouse model of hepatocellular carcinoma, Cancer Res. 57 (1997) 4249-4256.

[125] T. Miyagi, M. Koseki, S. Tsuiki, Comparative study of the levels of sialyltransferases responsible for the formation of sugar chains in glycoproteins and gangliosides in rat liver and hepatomas, Jpn. J. Cancer Res. 79 (1988) 742-749.

[126] F. Dall'Olio, M. Chiricolo, A. D'Errico, E. Gruppioni, A. Altimari, M. Fiorentino, W.F. Grigioni, Expression of $\beta$-galactoside $\alpha 2,6$ sialyltransferase and of $\alpha 2,6$-sialylated glycoconjugates in normal human liver, hepatocarcinoma, and cirrhosis, Glycobiology 14 (2004) 39-49.

[127] Y. Cao, A. Merling, P.R. Crocker, R. Keller, R. Schwartz-Albiez, Differential expression of $\beta$-galactoside $\alpha 2,6$ sialyltransferase and sialoglycans in normal and cirrhotic liver and hepatocellular carcinoma, Lab. Investig. 82 (2002) 1515-1524.

[128] T.C. Poon, C.H. Chiu, P.B. Lai, T.S. Mok, B. Zee, A.T. Chan, J.J. Sung, P.J. Johnson, Correlation and prognostic significance of $\beta$-galactoside $\alpha$-2,6-sialyltransferase and serum monosialylated alpha-fetoprotein in hepatocellular carcinoma, World J. Gastroenterol. 11 (2005) 6701-6706.

[129] R.S. Bresalier, R.W. Rockwell, R. Dahiya, Q.Y. Duh, Y.S. Kim, Cell surface sialoprotein alterations in metastatic murine colon cancer cell lines selected in an animal model for colon cancer metastasis, Cancer Res. 50 (1990) 1299-1307.

[130] F. Dall'Olio, N. Malagolini, G. Di Stefano, M. Ciambella, F. Serafini-Cessi, $\alpha$ 2,6 Sialylation of $\mathrm{N}$-acetyllactosaminic sequences in human colorectal cancer cell lines. Relationship with non-adherent growth, Int. J. Cancer 47 (1991) 291-297.

[131] F. Dall'Olio, N. Malagolini, F. Serafini-Cessi, Enhanced CMP-NeuAc:Gal B 1,4GlcNAc$\mathrm{R} \alpha 2,6$ sialyltransferase activity of human colon cancer xenografts in athymic nude mice and of xenograft-derived cell lines, Int. J. Cancer 50 (1992) 325-330.

[132] F. Dall'Olio, M. Chiricolo, P. Lollini, J.T. Lau, Human colon cancer cell lines permanently expressing $\alpha 2,6$ - sialylated sugar chains by transfection with rat $\beta$ galactoside $\alpha$ 2,6 sialyltransferase cDNA, Biochem. Biophys. Res. Commun. 211 (1995) 554-561.

[133] S. Lin, W. Kemmner, S. Grigull, P.M. Schlag, Cell surface $\alpha 2,6$-sialylation affects adhesion of breast carcinoma cells, Exp. Cell Res. 276 (2002) 101-110.

[134] E.C. Seales, G.A. Jurado, B.A. Brunson, J.K. Wakefield, A.R. Frost, S.L. Bellis, Hypersialylation of $\beta 1$ integrins, observed in colon adenocarcinoma, may contribute to cancer progression by up-regulating cell motility, Cancer Res. 65 (2005) 4645-4652.

[135] H. Yamamoto, Y. Kaneko, A. Rebbaa, E.G. Bremer, J.R. Moskal, $\alpha 2,6$-Sialyltransferase gene transfection into a human glioma cell line (U373 MG) results in decreased invasivity, J. Neurochem. 68 (1997) 2566-2576.

[136] E.C. Seales, G.A. Jurado, A. Singhal, S.L. Bellis, Ras oncogene directs expression of a differentially sialylated, functionally altered $\beta 1$ integrin, Oncogene 22 (2003) 7137-7145.

[137] M. Chiricolo, N. Malagolini, S. Bonfiglioli, F. Dall'Olio, Phenotypic changes induced by expression of $\beta$-galactoside $\alpha 2,6$ sialyltransferase I in the human colon cancer cell line SW948, Glycobiology 16 (2006) 146-154.

[138] F.M. Shaikh, E.C. Seales, W.C. Clem, K.M. Hennessy, Y. Zhuo, S.L. Bellis, Tumor cell migration and invasion are regulated by expression of variant integrin glycoforms, Exp. Cell Res. 314 (2008) 2941-2950.

[139] Y. Zhuo, S.L. Bellis, Emerging role of $\alpha 2,6$-sialic acid as a negative regulator of galectin binding and function, J. Biol. Chem. 286 (2011) 5935-5941.

[140] Y. Zhuo, R. Chammas, S.L. Bellis, Sialylation of $\beta 1$ integrins blocks cell adhesion to galectin-3 and protects cells against galectin-3-induced apoptosis, J. Biol. Chem. 283 (2008) 22177-22185.

[141] H. Yamamoto, A. Oviedo, C. Sweeley, T. Saito, J.R. Moskal, $\alpha 2,6-$ Sialylation of cellsurface N-glycans inhibits glioma formation in vivo, Cancer Res. 61 (2001) 6822-6829.

[142] H. Yamamoto, Y. Kaneko, D. Vandermulen, D. Kersey, E. Mkrdichian, L. Cerullo, J. Leestma, J.R. Moskal, The expression of CMP-NeuAc: Gal $\beta$ 1,4GlcNAc $\alpha 2,6$ sialyltransferase [EC 2.4.99.1] and glycoproteins bearing $\alpha$ 2,6- linked sialic acids in human brain tumours, Glycoconj. J. 12 (1995) 848-856.
[143] G. Dawson, J.R. Moskal, S.A. Dawson, Transfection of 2,6 and 2,3-sialyltransferase genes and GlcNAc-transferase genes into human glioma cell line U-373 MG affects glycoconjugate expression and enhances cell death, J. Neurochem. 89 (2004) 1436-1444.

[144] M. Hedlund, E. Ng, A. Varki, N.M. Varki, $\alpha 2-6$-Linked sialic acids on N-glycans modulate carcinoma differentiation in vivo, Cancer Res. 68 (2008) 388-394.

[145] A.F. Swindall, A.I. Londono-Joshi, M.J. Schultz, N. Fineberg, D.J. Buchsbaum, S.L. Bellis, ST6Gal-I protein expression is upregulated in human epithelial tumors and correlates with stem cell markers in normal tissues and colon cancer cell lines, Cancer Res. 73 (2013) 2368-2378.

[146] D.O. Croci, J.P. Cerliani, T. Dalotto-Moreno, S.P. Mendez-Huergo, I.D. Mascanfroni, S. Dergan-Dylon, M.A. Toscano, J.J. Caramelo, J.J. Garcia-Vallejo, J. Ouyang, E.A. Mesri, M.R. Junttila, C. Bais, M.A. Shipp, M. Salatino, G.A. Rabinovich, Glycosylationdependent lectin-receptor interactions preserve angiogenesis in anti-VEGF refractory tumors, Cell 156 (2014) 744-758.

[147] P. Stanley, Galectin-1 pulls the strings on VEGFR2, Cell 156 (2014) 625-626.

[148] K. Furukawa, K. Hamamura, H. Nakashima, K. Furukawa, Molecules in the signaling pathway activated by gangliosides can be targets of therapeutics for malignant melanomas, Proteomics 8 (2008) 3312-3316.

[149] K. Ko, K. Furukawa, T. Takahashi, T. Urano, Y. Sanai, M. Nagino, Y. Nimura, K. Furukawa, Fundamental study of small interfering RNAs for ganglioside GD3 synthase gene as a therapeutic target of lung cancers, Oncogene 25 (2006) $6924-6935$

[150] Y. Miura, M. Kainuma, H. Jiang, H. Velasco, P.K. Vogt, S. Hakomori, Reversion of the Jun-induced oncogenic phenotype by enhanced synthesis of sialosyllactosylceramide (GM3 ganglioside), Proc. Natl. Acad. Sci. U. S. A. 101 (2004) 16204-16209

[151] A. Prinetti, M. Aureli, G. Illuzzi, S. Prioni, V. Nocco, F. Scandroglio, N. Gagliano, G. Tredici, V. Rodriguez-Menendez, V. Chigorno, S. Sonnino, GM3 synthase overexpression results in reduced cell motility and in caveolin-1 upregulation in human ovarian carcinoma cells, Glycobiology 20 (2010) 62-77.

[152] P. Mukherjee, A.C. Faber, L.M. Shelton, R.C. Baek, T.C. Chiles, T.N. Seyfried, Thematic review series: sphingolipids. ganglioside GM3 suppresses the proangiogenic ef fects of vascular endothelial growth factor and ganglioside GD1a, J. Lipid Res. 49 (2008) 929-938.

[153] Z. Wang, Z. Sun, A.V. Li, K.J. Yarema, Roles for UDP-GlcNAc 2-epimerase/ManNAc 6kinase outside of sialic acid biosynthesis: modulation of sialyltransferase and BiP expression, GM3 and GD3 biosynthesis, proliferation, and apoptosis, and ERK1/2 phosphorylation, J. Biol. Chem. 281 (2006) 27016-27028.

[154] S. Yamashiro, S. Ruan, K. Furukawa, T. Tai, K.O. Lloyd, H. Shiku, K. Furukawa, Genetic and enzymatic basis for the differential expression of GM2 and GD2 gangliosides in human cancer cell lines, Cancer Res. 53 (1993) 5395-5400.

[155] H. Sasaki, T. Momoi, C. Yamanaka, T. Yorifuji, M. Kaji, H. Mikawa, Changes in the ganglioside composition of human neuroblastoma cells under different growth conditions, Int. J. Cancer 47 (1991) 742-745.

[156] G. Zeng, D.D. Li, L. Gao, S. Birkle, E. Bieberich, A. Tokuda, R.K. Yu, Alteration of ganglioside composition by stable transfection with antisense vectors against GD3synthase gene expression, Biochemistry 38 (1999) 8762-8769.

[157] G. Zeng, L. Gao, S. Birkle, R.K. Yu, Suppression of ganglioside GD3 expression in a rat F-11 tumor cell line reduces tumor growth, angiogenesis, and vascular endothelia growth factor production, Cancer Res. 60 (2000) 6670-6676.

[158] G. Zeng, L. Gao, R.K. Yu, Reduced cell migration, tumor growth and experimental metastasis of rat F-11 cells whose expression of GD3-synthase is suppressed, Int. J. Cancer 88 (2000) 53-57.

[159] X. Wang, P. Sun, A. Al Qamari, T. Tai, I. Kawashima, A.S. Paller, Carbohydrate-carbohydrate binding of ganglioside to integrin $\alpha 5$ modulates $\alpha 5 \beta 1$ function, J. Biol. Chem. 276 (2001) 8436-8444.

[160] A. Cazet, J. Lefebvre, E. Adriaenssens, S. Julien, M. Bobowski, A. Grigoriadis, A. Tutt, D. Tulasne, X. B. Le, P. Delannoy, GD3 synthase expression enhances proliferation and tumor growth of MDA-MB-231 breast cancer cells through c-Met activation, Mol. Cancer Res. 8 (2010) 1526-1535.

[161] A. Cazet, S. Groux-Degroote, B. Teylaert, K.M. Kwon, S. Lehoux, C. Slomianny, C.H. Kim, X. B. Le, P. Delannoy, GD3 synthase overexpression enhances proliferation and migration of MDA-MB-231 breast cancer cells, Biol. Chem. 390 (2009) 601-609.

[162] A. Cazet, M. Bobowski, Y. Rombouts, J. Lefebvre, A. Steenackers, I. Popa, Y Guerardel, X. B. Le, D. Tulasne, P. Delannoy, The ganglioside GD2 induces the constitutive activation of c-Met in MDA-MB-231 breast cancer cells expressing the GD3 synthase, Glycobiology 22 (2012) 806-816.

[163] K. Hamamura, M. Tsuji, H. Hotta, Y. Ohkawa, M. Takahashi, H. Shibuya, H Nakashima, Y. Yamauchi, N. Hashimoto, H. Hattori, M. Ueda, K. Furukawa, K. Furukawa, Functional activation of Src family kinase yes protein is essential for the enhanced malignant properties of human melanoma cells expressing ganglioside GD3, J. Biol. Chem. 286 (2011) 18526-18537.

[164] V.L. Battula, Y. Shi, K.W. Evans, R.Y. Wang, E.L. Spaeth, R.O. Jacamo, R. Guerra, A.A Sahin, F.C. Marini, G. Hortobagyi, S.A. Mani, M. Andreeff, Ganglioside GD2 identifies breast cancer stem cells and promotes tumorigenesis, J. Clin. Invest. 122 (2012) 2066-2078.

[165] M. Bobowski, A. Vincent, A. Steenackers, F. Colomb, I. S. van, S. Julien, P. Delannoy Estradiol represses the G(D3) synthase gene ST8SIA1 expression in human breast cancer cells by preventing NFkappaB binding to ST8SIA1 promoter, PLoS ONE 8 (2013) e62559.

[166] A. Steenackers, J. Vanbeselaere, A. Cazet, M. Bobowski, Y. Rombouts, F. Colomb, X.L. Bourhis, Y. Guerardel, P. Delannoy, Accumulation of unusual gangliosides GQ3 and GP3 in breast cancer cells expressing the GD3 synthase, Molecules 17 (2012) 9559-9572. 
[167] H. Sohn, Y.S. Kim, H.T. Kim, C.H. Kim, E.W. Cho, H.Y. Kang, N.S. Kim, C.H. Kim, S.E. Ryu, J.H. Lee, J.H. Ko, Ganglioside GM3 is involved in neuronal cell death, FASEB J. 20 (2006) 1248-1250.

[168] A. Hashiramoto, H. Mizukami, T. Yamashita, Ganglioside GM3 promotes cell migration by regulating MAPK and c-Fos/AP-1, Oncogene 25 (2006) 3948-3955.

[169] Y. Liu, S. Yan, A. Wondimu, D. Bob, M. Weiss, K. Sliwinski, J. Villar, V. Notario, M. Sutherland, A.M. Colberg-Poley, S. Ladisch, Ganglioside synthase knockout in oncogene-transformed fibroblasts depletes gangliosides and impairs tumor growth, Oncogene 29 (2010) 3297-3306.

[170] S. Mondal, S. Chandra, C. Mandal, Elevated mRNA level of hST6Gal I and hST3Gal V positively correlates with the high risk of pediatric acute leukemia, Leuk. Res. 34 (2010) 463-470.

[171] X.Q. Wang, P. Sun, L. Go, V. Koti, M. Fliman, A.S. Paller, Ganglioside GM3 promotes carcinoma cell proliferation via urokinase plasminogen activator-induced extracellular signal-regulated kinase-independent p70S6 kinase signaling, J. Invest. Dermatol. 126 (2006) 2687-2696.

[172] M. Noguchi, K. Kabayama, S. Uemura, B.W. Kang, M. Saito, Y. Igarashi, J. Inokuchi, Endogenously produced ganglioside GM3 endows etoposide and doxorubicin resistance by up-regulating Bcl-2 expression in 3LL Lewis lung carcinoma cells, Glycobiology 16 (2006) 641-650.

[173] Y. Gu, J. Zhang, W. Mi, J. Yang, F. Han, X. Lu, W. Yu, Silencing of GM3 synthase suppresses lung metastasis of murine breast cancer cells, Breast Cancer Res. 10 (2008) R1.

[174] M. Yanagisawa, S.S. Liour, R.K. Yu, Involvement of gangliosides in proliferation of immortalized neural progenitor cells, J. Neurochem. 91 (2004) 804-812.

[175] S.K. Moon, H.M. Kim, Y.C. Lee, C.H. Kim, Disialoganglioside (GD3) synthase gene expression suppresses vascular smooth muscle cell responses via the inhibition of ERK1/2 phosphorylation, cell cycle progression, and matrix metalloproteinase9 expression, J. Biol. Chem. 279 (2004) 33063-33070.

[176] Y. Koh, T. Tsunoda, M. Iwahashi, H. Yamaue, K. Ishimoto, H. Tanimura, H. Fukumoto, T. Nakamura, Y. Tatsumi, M. Shimizu, N. Saijo, K. Nishio, Decreased expression of $\alpha 2,8$ sialyltransferase and increased expression of $\beta 1,4 \mathrm{~N}$ acetylgalactosaminyltransferase in gastrointestinal cancers, Exp. Biol. Med. (Maywood) 227 (2002) 196-200

[177] P.D. Bos, X.H. Zhang, C. Nadal, W. Shu, R.R. Gomis, D.X. Nguyen, A.J. Minn, M.J. van de Vijver, W.L. Gerald, J.A. Foekens, J. Massague, Genes that mediate breast cancer metastasis to the brain, Nature 459 (2009) 1005-1009.

[178] B. Oster, K. Thorsen, P. Lamy, T.K. Wojdacz, L.L. Hansen, K. Birkenkamp-Demtroder, K.D. Sorensen, S. Laurberg, T.F. Orntoft, C.L. Andersen, Identification and validation of highly frequent $\mathrm{CpG}$ island hypermethylation in colorectal adenomas and carcinomas, Int. J. Cancer 129 (2011) 2855-2866

[179] R.A. Kroes, H. He, M.R. Emmett, C.L. Nilsson, F.E. Leach III, I.J. Amster, A.G. Marshall, J.R. Moskal, Overexpression of ST6GalNAcV, a ganglioside-specific $\alpha 2,6$ sialyltransferase, inhibits glioma growth in vivo, Proc. Natl. Acad. Sci. U. S. A. 107 (2010) 12646-12651

[180] M. Senda, A. Ito, A. Tsuchida, T. Hagiwara, T. Kaneda, Y. Nakamura, K. Kasama, M. Kiso, K. Yoshikawa, Y. Katagiri, Y. Ono, M. Ogiso, T. Urano, K. Furukawa, S. Oshima, K. Furukawa, Identification and expression of a sialyltransferase responsible for the synthesis of disialylgalactosylgloboside in normal and malignant kidney cells: downregulation of ST6GalNAc VI in renal cancers, Biochem. J. 402 (2007) 459-470.

[181] M.J. Schultz, A.F. Swindall, J.W. Wright, E.S. Sztul, C.N. Landen, S.L. Bellis, ST6Gal-I sialyltransferase confers cisplatin resistance in ovarian tumor cells, J. Ovarian Res. 6 (2013) 25.

[182] H. Ma, L. Cheng, K. Hao, Y. Li, X. Song, H. Zhou, L. Jia, Reversal effect of ST6GAL 1 on multidrug resistance in human leukemia by regulating the PI3K/Akt pathway and the expression of P-gp and MRP1, PLoS ONE 9 (2014) e85113.

[183] J.J. Park, J.Y. Yi, Y.B. Jin, Y.J. Lee, J.S. Lee, Y.S. Lee, Y.G. Ko, M. Lee, Sialylation of epidermal growth factor receptor regulates receptor activity and chemosensitivity to gefitinib in colon cancer cells, Biochem. Pharmacol. 83 (2012) 849-857.

[184] M. Nakano, R. Saldanha, A. Gobel, M. Kavallaris, N.H. Packer, Identification of glycan structure alterations on cell membrane proteins in desoxyepothilone B resistant leukemia cells, Mol. Cell. Proteomics 10 (2011) M111.

[185] Z. Zhang, Y. Zhao, L. Jiang, X. Miao, H. Zhou, L. Jia, Glycomic alterations are associated with multidrug resistance in human leukemia, Int. J. Biochem. Cell Biol. 44 (2012) 1244-1253.

[186] Y. Zhao, Y. Li, H. Ma, W. Dong, H. Zhou, X. Song, J. Zhang, L. Jia, Modification of sialylation mediates the invasive properties and chemosensitivity of human hepatocellular carcinoma, Mol. Cell. Proteomics 13 (2014) 520-536.

[187] W.J. Lee, Z.R. Majumder, D.I. Jeoung, H.J. Lee, S.H. Kim, S. Bae, Y.S. Lee, Organspecific gene expressions in C57BL/6 mice after exposure to low-dose radiation, Radiat. Res. 165 (2006) 562-569.

[188] M. Lee, H.J. Lee, S. Bae, Y.S. Lee, Protein sialylation by sialyltransferase involves radiation resistance, Mol. Cancer Res. 6 (2008) 1316-1325.

[189] M. Lee, H.J. Lee, W.D. Seo, K.H. Park, Y.S. Lee, Sialylation of integrin $\beta 1$ is involved in radiation-induced adhesion and migration in human colon cancer cells, Int. J. Radiat. Oncol. Biol. Phys. 76 (2010) 1528-1536.

[190] M. Lee, J. Park, Y.S. Lee, Adhesion of ST6Gal I-mediated human colon cancer cells to fibronectin contributes to cell survival by integrin $\beta 1$-mediated paxillin and AKT activation, Oncol. Rep. 23 (2010) 757-761.

[191] J. Seidler, R. Durzok, C. Brakebusch, N. Cordes, Interactions of the integrin subunit B1A with protein kinase B/Akt, p130Cas and paxillin contribute to regulation of radiation survival, Radiother. Oncol. 76 (2005) 129-134

[192] P. Delannoy, H. Pelczar, V. Vandamme, A. Verbert, Sialyltransferase activity in FR3T3 cells transformed with ras oncogene: decreased CMP-Neu5Ac:Gal $\beta 1$ 3GalNAc $\alpha-2,3-$ sialyltransferase, Glycoconj. J. 10 (1993) 91-98.
[193] E.W. Easton, J.G. Bolscher, D.H. van den Eijnden, Enzymatic amplification involving glycosyltransferases forms the basis for the increased size of asparagine-linked glycans at the surface of NIH 3T3 cells expressing the N-ras proto-oncogene, J. Biol. Chem. 266 (1991) 21674-21680.

[194] N. Le Marer, V. Laudet, E.C. Svensson, H. Cazlaris, B. Van Hille, C. Lagrou, D. Stehelin, J. Montreuil, A. Verbert, P. Delannoy, The c-Ha-ras oncogene induces increased expression of $\beta$-galactoside $\alpha$-2, 6-sialyltransferase in rat fibroblast (FR3T3) cells, Glycobiology 2 (1992) 49-56.

[195] M. Dalziel, F. Dall'Olio, A. Mungul, V. Piller, F. Piller, Ras oncogene induces $\beta-$ galactoside $\alpha 2,6$-sialyltransferase (ST6Gal I) via a RalGEF-mediated signal to its housekeeping promoter, Eur. J. Biochem. 271 (2004) 3623-3634.

[196] C. Sakakura, K. Hasegawa, K. Miyagawa, S. Nakashima, T. Yoshikawa, S. Kin, Y. Nakase, S. Yazumi, H. Yamagishi, T. Okanoue, T. Chiba, A. Hagiwara, Possible involvement of RUNX3 silencing in the peritoneal metastases of gastric cancers, Clin. Cancer Res. 11 (2005) 6479-6488.

[197] S. Yu, J. Fan, L. Liu, L. Zhang, S. Wang, J. Zhang, Caveolin-1 up-regulates integrin $\alpha 2,6$-sialylation to promote integrin $\alpha 5 \beta 1$-dependent hepatocarcinoma cell adhesion, FEBS Lett. 587 (2013) 782-787.

[198] C.S. Mayanil, D. George, B. Mania-Farnell, C.L. Bremer, D.G. McLone, E.G. Bremer, Overexpression of murine pax3 increases NCAM polysialylation in a human medulloblastoma cell line, J. Biol. Chem. 275 (2000) 23259-23266.

[199] J.P. Peyrat, M.A. Recchi, M. Hebbar, V. Pawlowski, L. Hornez, X. Dong-Lebouhris, H. Hondermarck, A. Harduin-Lepers, P. Delannoy, Regulation of sialyltransferase expression by estradiol and 4-OH- tamoxifen in the human breast cancer cell MCF7, Mol. Cell Biol. Res. Commun. 3 (2000) 48-52.

[200] N.Y. Kang, C.H. Kim, K.S. Kim, J.H. Ko, J.H. Lee, Y.K. Jeong, Y.C. Lee, Expression of the human CMP-NeuAc:GM3 $\alpha 2,8$-sialyltransferase (GD3 synthase) gene through the NF-kB activation in human melanoma SK-MEL-2 cells, Biochim. Biophys. Acta 1769 (2007) 622-630.

[201] K. Hatano, Y. Miyamoto, N. Nonomura, Y. Kaneda, Expression of gangliosides, GD1a, and sialyl paragloboside is regulated by NF-kappaB-dependent transcriptional control of alpha2,3-sialyltransferase I, II, and VI in human castrationresistant prostate cancer cells, Int. J. Cancer 129 (2011) 1838-1847.

[202] L.L. Duan, P. Guo, Y. Zhang, H.L. Chen, Regulation of metastasis-suppressive gene Nm23-H1 on glycosyl-transferases involved in the synthesis of sialyl Lewis antigens, J. Cell. Biochem. 94 (2005) 1248-1257.

[203] S.W. Son, K.H. Song, H.Y. Kwon, K.S. Kim, C.H. Kim, K.B. Oh, Y.K. Choo, Y.C. Lee, Transcriptional activation of pig Gal 31,3 GalNAc $\alpha 2,3$-sialyltransferase (pST3Gal I) gene by TGF- $\beta 1$ in porcine kidney PK-15 cells, Biochem. Biophys. Res. Commun. 414 (2011) 159-164.

[204] J. Lee, S. Ballikaya, K. Schonig, C.R. Ball, H. Glimm, J. Kopitz, J. Gebert, Transforming growth factor beta receptor 2 (TGFBR2) changes sialylation in the microsatellite unstable (MSI) colorectal cancer cell line HCT116, PLoS ONE 8 (2013) e57074.

[205] K. Hatano, Y. Miyamoto, M. Mori, K. Nimura, Y. Nakai, N. Nonomura, Y. Kaneda, Androgen-regulated transcriptional control of sialyltransferases in prostate cancer cells, PLoS ONE 7 (2012) e31234.

[206] L. Trusolino, A. Bertotti, P.M. Comoglio, MET signalling: principles and functions in development, organ regeneration and cancer, Nat. Rev. Mol. Cell Biol. 11 (2010) 834-848.

[207] A.R. Todeschini, J.N. Dos Santos, K. Handa, S.I. Hakomori, Ganglioside GM2tetraspanin CD82 complex inhibits met and its cross-talk with integrins, providing a basis for control of cell motility through glycosynapse, J. Biol. Chem. 282 (2007) 8123-8133.

[208] A.R. Todeschini, J.N. Dos Santos, K. Handa, S.I. Hakomori, Ganglioside GM2/GM3 complex affixed on silica nanospheres strongly inhibits cell motility through CD82/cMetmediated pathway, Proc. Natl. Acad. Sci. U. S. A. 105 (2008) 1925-1930

[209] A.R. Todeschini, S.I. Hakomori, Functional role of glycosphingolipids and gangliosides in control of cell adhesion, motility, and growth, through glycosynaptic microdomains, Biochim. Biophys. Acta 1780 (2008) 421-433.

[210] K. Hamamura, M. Tsuji, Y. Ohkawa, H. Nakashima, S. Miyazaki, T. Urano, N. Yamamoto, M. Ueda, K. Furukawa, K. Furukawa, Focal adhesion kinase as well as p130Cas and paxillin is crucially involved in the enhanced malignant properties under expression of ganglioside GD3 in melanoma cells, Biochim. Biophys. Acta 1780 (2008) 513-519.

[211] H. Shibuya, K. Hamamura, H. Hotta, Y. Matsumoto, Y. Nishida, H. Hattori, K. Furukawa, M. Ueda, K. Furukawa, Enhancement of malignant properties of human osteosarcoma cells with disialyl gangliosides GD2/GD3, Cancer Sci. 103 (2012) 1656-1664.

[212] S. Fukumoto, T. Mutoh, T. Hasegawa, H. Miyazaki, M. Okada, G. Goto, K. Furukawa, T. Urano, GD3 synthase gene expression in PC12 cells results in the continuous activation of TrkA and ERK1/2 and enhanced proliferation, J. Biol. Chem. 275 (2000) 5832-5838.

[213] K. Hamamura, K. Furukawa, T. Hayashi, T. Hattori, J. Nakano, H. Nakashima, T. Okuda, H. Mizutani, H. Hattori, M. Ueda, T. Urano, K.O. Lloyd, K. Furukawa, Ganglioside GD3 promotes cell growth and invasion through p130Cas and paxillin in malignant melanoma cells, Proc. Natl. Acad. Sci. U. S. A. 102 (2005) 11041-11046.

[214] E.G. Bremer, S. Hakomori, D.F. Bowen-Pope, E. Raines, R. Ross, Gangliosidemediated modulation of cell growth, growth factor binding, and receptor phosphorylation, J. Biol. Chem. 259 (1984) 6818-6825

[215] E.G. Bremer, J. Schlessinger, S. Hakomori, Ganglioside-mediated modulation of cell growth. Specific effects of GM3 on tyrosine phosphorylation of the epidermal growth factor receptor, J. Biol. Chem. 261 (1986) 2434-2440.

[216] C. Lohrisch, M. Piccart, An overview of HER2, Semin. Oncol. 28 (2001) 3-11.

[217] S.J. Yoon, K. Nakayama, T. Hikita, K. Handa, S.I. Hakomori, Epidermal growth factor receptor tyrosine kinase is modulated by GM3 interaction with N-linked GlcNAc termini of the receptor, Proc. Natl. Acad. Sci. U. S. A. 103 (2006) 18987-18991. 
[218] N. Kawashima, S.J. Yoon, K. Itoh, K. Nakayama, Tyrosine kinase activity of epidermal growth factor receptor is regulated by GM3 binding through carbohydrate to carbohydrate interactions, J. Biol. Chem. 284 (2009) 6147-6155.

[219] K. Handa, S.I. Hakomori, Carbohydrate to carbohydrate interaction in development process and cancer progression, Glycoconj. J. 29 (2012) 627-637.

[220] F. Guan, K. Handa, S.I. Hakomori, Regulation of epidermal growth factor receptor through interaction of ganglioside GM3 with GlcNAc of N-linked glycan of the receptor: demonstration in IdID cells, Neurochem. Res. 36 (2011) 1645-1653.

[221] E. Sottocornola, R. Misasi, V. Mattei, L. Ciarlo, R. Gradini, T. Garofalo, B. Berra, I. Colombo, M. Sorice, Role of gangliosides in the association of ErbB2 with lipid rafts in mammary epithelial HC11 cells, FEBS J. 273 (2006) 1821-1830.

[222] S. Milani, E. Sottocornola, S. Zava, P. Berselli, B. Berra, I. Colombo, Ganglioside $\mathrm{GM}(3)$ is stably associated to tyrosine-phosphorylated ErbB2/EGFR receptor complexes and EGFR monomers, but not to ErbB2, Biochim. Biophys. Acta 1771 (2007) 873-878.

[223] S. Milani, E. Sottocornola, S. Zava, M. Galbiati, B. Berra, I. Colombo, Gangliosides influence EGFR/ErbB2 heterodimer stability but they do not modify EGF-dependent ErbB2 phosphorylation, Biochim. Biophys. Acta 1801 (2010) 617-624.

[224] M. Noguchi, T. Suzuki, K. Kabayama, H. Takahashi, H. Chiba, M. Shiratori, S. Abe, A Watanabe, M. Satoh, T. Hasegawa, S. Tagami, A. Ishii, M. Saitoh, M. Kaneko, K. Iseki, Y. Igarashi, J. Inokuchi, GM3 synthase gene is a novel biomarker for histological classification and drug sensitivity against epidermal growth factor receptor tyrosine kinase inhibitors in non-small cell lung cancer, Cancer Sci. 98 (2007) 1625-1632.

[225] X.Q. Wang, Q. Yan, P. Sun, J.W. Liu, L. Go, S.M. McDaniel, A.S. Paller, Suppression of epidermal growth factor receptor signaling by protein kinase C-alpha activation requires CD82, caveolin-1, and ganglioside, Cancer Res. 67 (2007) 9986-9995.

[226] Y. Liu, Y. Su, M. Wiznitzer, O. Epifano, S. Ladisch, Ganglioside depletion and EGF responses of human GM3 synthase-deficient fibroblasts, Glycobiology 18 (2008) 593-601.

[227] T.W. Chung, S.J. Kim, H.J. Choi, K.J. Kim, M.J. Kim, S.H. Kim, H.J. Lee, J.H. Ko, Y.C. Lee, A. Suzuki, C.H. Kim, Ganglioside GM3 inhibits VEGF/VEGFR-2-mediated angiogenesis: direct interaction of GM3 with VEGFR-2, Glycobiology 19 (2009) 229-239.

[228] Y.C. Liu, H.Y. Yen, C.Y. Chen, C.H. Chen, P.F. Cheng, Y.H. Juan, C.H. Chen, K.H. Khoo, C. J. Yu, P.C. Yang, T.L. Hsu, C.H. Wong, Sialylation and fucosylation of epidermal growth factor receptor suppress its dimerization and activation in lung cancer cells, Proc. Natl. Acad. Sci. U. S. A. 108 (2011) 11332-11337.

[229] A. Minami, Y. Shimono, K. Mizutani, K. Nobutani, K. Momose, T. Azuma, Y. Takai, Reduction of the ST6 $\beta$-galactosamide $\alpha$-2,6-sialyltransferase 1 (ST6GAL1)-catalyzed sialylation of nectin-like molecule 2 /cell adhesion molecule 1 and enhancement of ErbB2/ErbB3 signaling by microRNA-199a, J. Biol. Chem. 288 (2013) $11845-11853$.

[230] R.O. Hynes, Integrins: bidirectional, allosteric signaling machines, Cell 110 (2002) 673-687.

[231] M. Moser, K.R. Legate, R. Zent, R. Fassler, The tail of integrins, talin, and kindlins, Science 324 (2009) 895-899.

[232] Y. Kawakami, K. Kawakami, W.F. Steelant, M. Ono, R.C. Baek, K. Handa, D.A. Withers, S. Hakomori, Tetraspanin CD9 is a "proteolipid," and its interaction with $\alpha 3$ integrin in microdomain is promoted by GM3 ganglioside, leading to inhibition of laminin-5-dependent cell motility, J. Biol. Chem. 277 (2002) 34349-34358.

[233] M. Ono, K. Handa, S. Sonnino, D.A. Withers, H. Nagai, S. Hakomori, GM3 ganglioside inhibits CD9-facilitated haptotactic cell motility: coexpression of GM3 and CD9 is essential in the downregulation of tumor cell motility and malignancy, Biochemistry 40 (2001) 6414-6421.

[234] R. Seidenfaden, A. Krauter, F. Schertzinger, R. Gerardy-Schahn, H. Hildebrandt, Polysialic acid directs tumor cell growth by controlling heterophilic neural cell adhesion molecule interactions, Mol. Cell. Biol. 23 (2003) 5908-5918.

[235] J.A. Kelber, T. Reno, S. Kaushal, C. Metildi, T. Wright, K. Stoletov, J.M. Weems, F.D. Park, E. Mose, Y. Wang, R.M. Hoffman, A.M. Lowy, M. Bouvet, R.L. Klemke, KRas induces a Src/PEAK1/ErbB2 kinase amplification loop that drives metastatic growth and therapy resistance in pancreatic cancer, Cancer Res. 72 (2012) 2554-2564.

[236] F. Dall'Olio, D. Trere, Expression of $\alpha 2,6$-sialylated sugar chains in normal and neoplastic colon tissues. Detection by digoxigenin-conjugated Sambucus nigra agglutinin, Eur. J. Histochem. 37 (1993) 257-265.

[237] T. Sata, J. Roth, C. Zuber, B. Stamm, P.U. Heitz, Expression of $\alpha 2,6$-linked sialic acid residues in neoplastic but not in normal human colonic mucosa. A lectin-gold cytochemical study with Sambucus nigra and Maackia amurensis lectins, Am. J. Pathol. 139 (1991) 1435-1448

[238] W. Kemmner, D. Kruck, P. Schlag, Different sialyltransferase activities in human colorectal carcinoma cells from surgical specimens detected by specific glycoprotein and glycolipid acceptors, Clin. Exp. Metastasis 12 (1994) 245-254.

[239] F. Dall'Olio, M. Chiricolo, C. Ceccarelli, F. Minni, D. Marrano, D. Santini, $\beta-$ galactoside $\alpha 2,6$ sialyltransferase in human colon cancer: contribution of multiple transcripts to regulation of enzyme activity and reactivity with Sambucus nigra agglutinin, Int. J. Cancer 88 (2000) 58-65.

[240] Y. Qiu, T.H. Patwa, L. Xu, K. Shedden, D.E. Misek, M. Tuck, G. Jin, M.T. Ruffin, D.K. Turgeon, S. Synal, R. Bresalier, N. Marcon, D.E. Brenner, D.M. Lubman, Plasma glycoprotein profiling for colorectal cancer biomarker identification by lectin glycoarray and lectin blot, J. Proteome Res. 7 (2008) 1693-1703.

[241] C. Vazquez-Martin, E. Gil-Martin, A. Fernandez-Briera, Elevation of ST6Gal I activity in malignant and transitional tissue in human colorectal cancer, Oncology 69 (2005) 436-444.

[242] L. Jun, W. Yuanshu, X. Yanying, X. Zhongfa, Y. Jian, W. Fengling, Q. Xianjun, N. Kokudo, T. Wei, Z. Weixia, C. Shuxiang, Altered mRNA expressions of sialyltransferases in human gastric cancer tissues, Med. Oncol. 29 (2012) 84-90.

[243] S. Gretschel, W. Haensch, P.M. Schlag, W. Kemmner, Clinical relevance of sialyltransferases ST6GAL-I and ST3GAL-III in gastric cancer, Oncology 65 (2003) $139-145$.

[244] G.O. Elpek, T. Gelen, G. Karpuzoglu, T. Karpuzoglu, N. Keles, Clinicopathologic evaluation of CDw75 antigen expression in patients with gastric carcinoma, J. Pathol. 193 (2001) 169-174.

[245] P.O. Skacel, A.J. Edwards, C.T. Harrison, W.M. Watkins, Enzymic control of the expression of the X determinant (CD15) in human myeloid cells during maturation: the regulatory role of 6- sialytransferase, Blood 78 (1991) 1452-1460.

[246] K. Fukushima, S. Hara-Kuge, A. Seko, Y. Ikehara, K. Yamashita, Elevation of $\alpha 2,6$ sialyltransferase and $\alpha 1,2$ fucosyltransferase activities in human choriocarcinoma, Cancer Res. 58 (1998) 4301-4306.

247] P.H. Wang, Y.F. Li, C.M. Juang, Y.R. Lee, H.T. Chao, Y.C. Tsai, C.C. Yuan, Altered mRNA expression of sialyltransferase in squamous cell carcinomas of the cervix, Gynecol. Oncol. 83 (2001) 121-127.

[248] P.H. Wang, W.L. Lee, Y.R. Lee, C.M. Juang, Y.J. Chen, H.T. Chao, Y.C. Tsai, C.C. Yuan, Enhanced expression of alpha 2,6-sialyltransferase ST6Gal I in cervical squamous cell carcinoma, Gynecol. Oncol. 89 (2003) 395-401.

[249] P.H. Wang, Y.F. Li, C.M. Juang, Y.R. Lee, H.T. Chao, H.T. Ng, Y.C. Tsai, C.C. Yuan, Expression of sialyltransferase family members in cervix squamous cell carcinoma correlates with lymph node metastasis, Gynecol. Oncol. 86 (2002) 45-52.

[250] D. Lopez-Morales, N. Velazquez-Marquez, O. Valenzuela, G. Santos-Lopez, J. ReyesLeyva, V. Vallejo-Ruiz, Enhanced sialyltransferases transcription in cervica intraepithelial neoplasia, Invest. Clin. 50 (2009) 45-53.

[251] P.H. Wang, W.L. Lee, C.M. Juang, Y.H. Yang, W.H. Lo, C.R. Lai, S.L. Hsieh, C.C. Yuan, Altered mRNA expressions of sialyltransferases in ovarian cancers, Gynecol. Oncol. 99 (2005) 631-639.

[252] Y. Kaneko, H. Yamamoto, D.S. Kersey, K.J. Colley, J.E. Leestma, J.R. Moskal, The expression of Gal $\beta$ 1,4GlcNAc $\alpha 2,6$ sialyltransferase and $\alpha$ 2,6-linked sialoglycoconjugates in human brain tumors, Acta Neuropathol. (Berl.) 91 (1996) 284-292.

[253] J. Souady, M. Hulsewig, U. Distler, J. Haier, A. Denz, C. Pilarsky, N. Senninger, K. Dreisewerd, J. Peter-Katalinic, J. Muthing, Differences in CD75s- and iso-CD75sganglioside content and altered mRNA expression of sialyltransferases ST6GAL1 and ST3GAL6 in human hepatocellular carcinomas and nontumoral liver tissues, Glycobiology 21 (2011) 584-594.

[254] W. Reed, B.K. Erikstein, S. Funderud, R. Lilleng, K. Tvedt, J.M. Nesland, CDw75 antigen expression in breast lesions, Pathol. Res. Pract. 189 (1993) 394-398.

[255] M.H. Shah, S.D. Telang, P.M. Shah, P.S. Patel, Tissue and serum $\alpha 2-3-$ and $\alpha 2-6-$ linkage specific sialylation changes in oral carcinogenesis, Glycoconj. J. 25 (2008) 279-290.

[256] G.N. Raval, D.D. Patel, L.J. Parekh, J.B. Patel, M.H. Shah, P.S. Patel, Evaluation of serum sialic acid, sialyltransferase and sialoproteins in oral cavity cancer, Oral Dis. 9 (2003) 119-128.

[257] S.A. Ferreira, J.L. Vasconcelos, R.C. Silva, C.L. Cavalcanti, C.L. Bezerra, M.J. Rego, E.I. Beltrao, Expression patterns of $\alpha 2,3$-sialyltransferase I and $\alpha 2,6$-sialyltransferase I in human cutaneous epithelial lesions, Eur. J. Histochem. 57 (2013) e7. 